This PDF is a selection from a published volume from the National Bureau of Economic Research

Volume Title: Housing and the Financial Crisis

Volume Author/Editor: Edward L. Glaeser and Todd Sinai, editors

Volume Publisher: University of Chicago Press

Volume ISBN: 978-0-226-03058-6

Volume URL: http://www.nber.org/books/glae11-1

Conference Date: November 17-18, 2011

Publication Date: August 2013

Chapter Title: The Supply Side of the Housing Boom and Bust of the 2000s

Chapter Author(s): Andrew Haughwout, Richard W. Peach, John Sporn, Joseph Tracy

Chapter URL: http://www.nber.org/chapters/c12620

Chapter pages in book: (p. 69 - 104) 


\title{
The Supply Side of the Housing Boom and Bust of the 2000s
}

\author{
Andrew Haughwout, Richard W. Peach, John Sporn, \\ and Joseph Tracy
}

\subsection{Four Questions about Housing Supply over the 2000s Cycle}

The boom and subsequent bust of housing construction and prices over the 2000s is widely regarded as a principal contributor to the financial panic of 2007 and the ensuing "Great Recession." As of this writing, it appears that single-family housing starts are finally beginning a gradual recovery roughly seven years after their previous peak in 2005:Q3. Nonetheless, the overall level of housing starts and sales remain at depressed levels as the economy slowly resolves the legacy of excess supply and sharply lower prices. Based on the CoreLogic national index, home prices have fallen 30 percent from their peak in early 2006, returning to levels that prevailed in mid-2003. Roughly one in four homeowners with a mortgage has combined mortgage loan balances that exceed the value of the property. Over 2.6 million foreclosures have been completed since 2008 with 1.9 million

Andrew Haughwout is a vice president in the Research and Statistics Group at the Federal Reserve Bank of New York. Richard W. Peach is a senior vice president in the Macroeconomic and Monetary Studies Function of the Federal Reserve Bank of New York. John Sporn is an assistant economist in the Research and Statistics Group at the Federal Reserve Bank of New York. Joseph Tracy is an executive vice president and senior advisor to the president at the Federal Reserve Bank of New York.

These views are those of the authors and do not necessarily reflect the views of the Federal Reserve Bank of New York or the Federal Reserve System. The authors would like to thank David Crowe, Stephen Melman, and Elliot Eisenberg of the National Association of Home Builders (NAHB) for providing various data and suggestions. We would also like to thank Dan Oppenheim from Credit Suisse, Nishu Sood from Deutsche Bank, and Joshua Pollard from Goldman Sachs for sharing their knowledge of the home-building sector. Sarah Stein provided expert assistance with the CoStar land sales data. For acknowledgments, sources of research support, and disclosure of the authors' material financial relationships, if any, please see http:// www.nber.org/chapters/c12620.ack. 
foreclosures in process. ${ }^{1}$ Another 1.3 million loans are currently ninety or more days delinquent and very likely to move into the foreclosure process.

Much has been written about the demand side of this pronounced housing cycle, in particular the innovations in mortgage finance and loosening of underwriting standards that greatly expanded the pool of potential home buyers. In this chapter, we take a closer look at developments on the supply side of the housing market, and bring prior theories and previous analysis of housing supply face-to-face with data from the 2000s cycle. We focus our discussion on four key issues.

First, how much excess housing production occurred during the boom phase of the cycle and how far along is the correction? While it is now clear that too much housing was built in the United States in the boom phase, identifying how much and where overbuilding occurred remain important issues. We also explore the issue of whether supply elasticity played a role in that geographic dispersion. Our results suggest that 3 to 3.5 million excess housing units were produced during the boom. Excess housing production was a national phenomenon, but excess supply is positively related to housing supply elasticities.

Second, we look at trends in the characteristics of new single-family homes built prior to, during, and after the construction boom to assess what effect, if any, the boom may have had on those trends. The number of excess units put in place during the boom is only a partial measure of its distortive effect on resource allocation; to be complete we must also understand the quality of those units. The effect of booms on asset quality is ambiguous in theory, so evidence from the housing market, where the quality of new construction compared to the existing stock is relatively easy to measure, is valuable. We find that throughout the boom, the quality of new units - both observable and unobservable - appears to have remained high.

Our third question is how the home-building industry changed as prices boomed during the 2000s. We present new evidence regarding the restructuring of the industry that took place from the mid-1990s to the mid-2000s and ask whether this restructuring may have contributed in some way to the overbuilding that took place. We find that a significant amount of consolidation occurred in the industry over this period, as large builders got larger and increasingly relied on the equity markets to finance their projects. These large builders appear to have been major contributors to oversupply as they had projects in the pipeline even after prices began to fall, and in spite of the fact that capital markets signaled this risk well before banks began to tighten lending standards.

Finally, we address the important question of whether these large developers reaped excess profits from the boom, or whether excess demand simply of National Banks, and Office of Thrift Supervision, US Department of the Treasury. 
drove up land values in specific markets, enriching landowners. We present new evidence on transaction volumes and prices for vacant land during the boom and bust, and combine them with our estimates of excess returns in the building industry. In addition, we examine whether large builders earned on average excess returns over this period of consolidation. In addition, we explore whether any excess returns were higher during the height of the housing boom. These data allow us to conclude that both builders and landowners shared in the excess profits generated by the boom.

\subsection{Literature Review}

Among our four questions, the first-documenting excess supply and its sources - has received the most attention in previous literature. There is considerable interest in evaluating the efficiency of various asset markets, including housing. Case and Shiller (1989) report evidence of serial correlation in quality-adjusted housing returns. If housing markets were fully efficient, then future housing returns could not be predicted based on current information. There are frictions on both the demand side and the supply side of the housing market that might lead to imperfect arbitrage. On the demand side, housing is heterogeneous in a number of dimensions and there are significant transaction costs associated with buying and selling property. On the supply side, there are time frictions involved in the supply of new housing that limit how quickly builders can respond to any mispricing. There may also be costs of adjustment in housing supply that cause builders to spread any supply response out over time (Topel and Rosen 1988). These results imply that builders could get caught with excess supply in the pipeline if prices turn quickly and unexpectedly.

Rosenthal (1999) tests for inefficiencies on the supply side, taking into account that builders cannot instantaneously supply new housing to the market. He uses data on single family detached housing sales in Vancouver, BC, from 1979 to 1989 to estimate a quality-adjusted price of housing using hedonic regressions. An error correction model is estimated to determine how quickly deviations in quality-adjusted prices from building costs are dissipated. The results for a standard building indicate that 96 percent of a short-run price shock disappears within two quarters. When estimates of these price shocks are added to a construction equation, they are not significant. This is consistent with additional evidence that during this period builders required two to three quarters to complete a construction project. Consequently, the observed price shocks were on average too short-lived for builders to earn excess profits by adjusting their construction activity in response to the shocks. Rosenthal concludes that any inefficiencies must originate in the land markets.

Glaeser, Gyourko, and Saiz (2008) explore the role of housing supply elasticity in how possible housing bubbles would manifest themselves in 
different markets. Their model predictions are that any irrational demand during a bubble will result in higher prices and a more prolonged duration of the bubble in markets where housing is less elastically supplied. In contrast, in markets with relatively elastic supply, bubbles should result in more new residential investment and consequently less of a price response. This muted price response also makes it likely that the bubble will be shorter in duration. They test these predictions using the proxy for housing supply elasticity developed in Saiz (2010). ${ }^{2}$ Their estimates confirm that prices react relatively more than quantities in housing markets with inelastic supply, and that as a consequence periods of significantly high prices relative to replacement costs on average last longer. However, they note that several of the markets that experienced the largest booms in the recent cycle have high measured supply elasticities. These markets also demonstrated little variability of prices relative to replacement costs prior to the recent cycle. While having an elastic housing supply limits the likelihood of a serious housing bubble in a local market, it clearly does not prevent one from happening.

While an elastic supply of housing can limit the price rise associated with a temporary period of irrational exuberance in demand, given the durability of housing the larger supply response during the boom means that prices may fall below their preboom levels once demand again reflects fundamental factors. ${ }^{3}$ Housing supply is nearly completely inelastic at the current stock of housing for prices below replacement costs (Glaeser and Gyourko 2008). This implies that if housing demand reverts back to its preboom level when the bubble bursts, then prices will overshoot to the down side in elastically supplied markets.

This is illustrated in figure 2.1, which contrasts two local housing markets - one with a completely inelastic short-run housing supply curve, $S(I)$, and one with an elastic short-run supply curve, $S(E)$. The replacement cost of housing is given by $C$ and initially both markets start out with prices equal to replacement cost at point $A$. A housing bubble develops, which shifts out housing demand in both markets from $D_{0}$ to $D_{1}$. There is no supply response in the inelastic market so prices ration this irrational exuberance by increasing to $P_{1}(I)$ as indicated at point $C$. In contrast, in the elastic supply market both prices and new housing supply react to the outward shift in demand. As a consequence, prices adjust by less than in the inelastic market, rising only to $P_{1}(E)$ as indicated at point $B$. When the bubble bursts, assume that demand reverts back to $D_{0}$. Prices in the inelastic market decline back to their prebubble level of $P_{0}$. However, due to the new housing supply added to the

2. This proxy is the percent of land within a 50 kilometer radius area that has a slope of less than 15 degrees.

3. The tendency for house prices to "overshoot" on the down side will be magnified if lending standards are significantly tightened during the bust phase of the housing cycle and to the extent that the bursting of the housing bubble weakens fundamental housing demand due to higher rates of unemployment. 


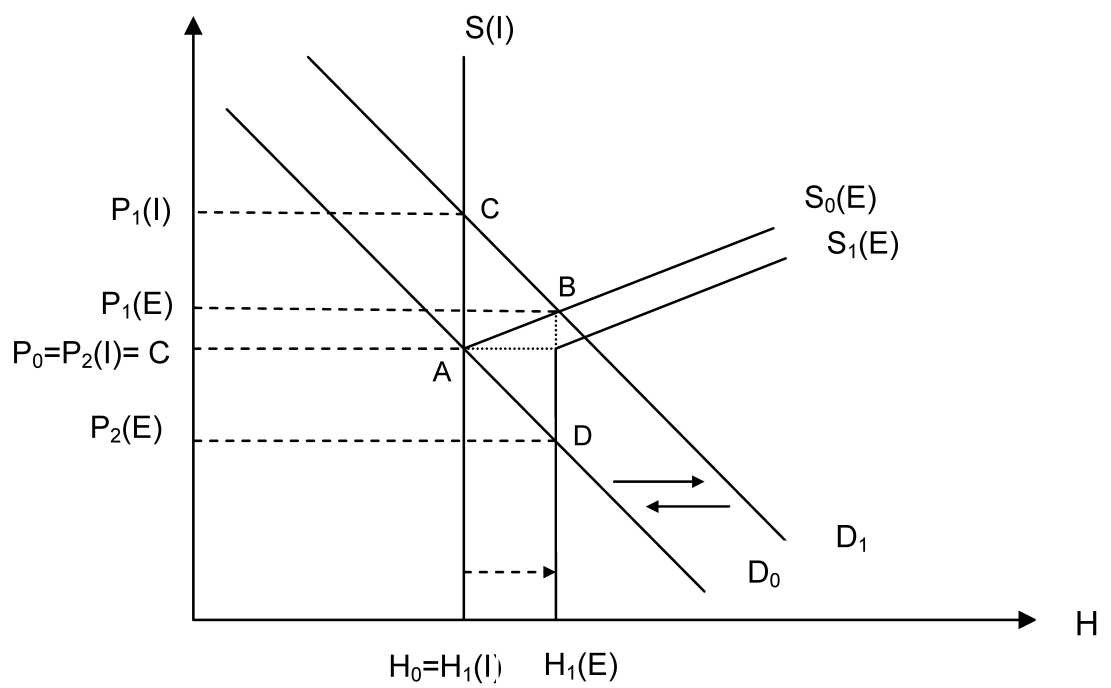

Fig. 2.1 House price dynamics in inelastic and elastic supply markets

elastic market and the durable nature of housing, prices in the elastic market overshoot on the downward side to $P_{2}(E)<P_{0} \cdot{ }^{4}$ As fundamental demand begins to expand in the elastic supply market, prices will adjust upward, but there will initially be no new building activity. Once prices have recovered to the replacement cost, new supply will again be added to the market. Overbuilding, to the extent that it occurs, has important consequences for local housing markets.

There is also an emerging literature on rational models of overbuilding. DeCoster and Strange (2010) argue that rational overbuilding may occur in markets with uncertainty due to herding behavior by builders. They explore statistical and reputational models of herding behavior (see Banerjee 1992 and Welch 1992). In statistical herding, a builder may choose to ignore a bad signal about future demand prospects in the market if this builder can infer that other builders have received more positive signals. This tendency to ignore bad signals is more pronounced if the market is characterized by leading builders who are perceived as having high-quality information regarding market conditions and who may act as "first movers" in the market. In a market characterized by a few large builders and many small builders, statistical herding is most likely to be exhibited by the small builders who are attempting to free ride on the information gathered and acted upon by the large builders. Changes in market structure in the building industry can

4. If lending standards are tightened following the bust relative to the preboom period, then the demand for housing will be contracted even further, magnifying the downward overshoot in prices. Also, if the burst of the housing bubble results in a recession that increases unemployment then this will further put downward pressure on home prices. 
impact the likelihood of overbuilding due to statistical herding. As a market becomes more concentrated, there is a trade-off between the increased likelihood that the smaller builders will discount their signals and follow the market leaders and the possible greater reliability of the signals received by the market leaders. Reputational herding may take place if banks have imperfect information on the quality of developers. The likelihood that a bank will cut off funding to a particular builder may be lower if that builder mimics the actions taken by another builder. This type of herding adds noise to the signal that the bank uses to attempt to discriminate between the builders.

\subsection{How Much Overbuilding Occurred during the Boom?}

A question of interest is how much excess supply was created during the boom in housing construction. To begin to answer that question, figure 2.2 presents a half-century time series of housing starts per 1,000 people, broken out by single-family and multifamily units. From the mid-1960s to the late 1980 s, housing production expressed in these terms was quite volatile around a downward trend. Then, from the early 1990s until 2005, a strong upward trend was evident, particularly for single-family units. Following the peak in 2005 , total housing starts fell a cumulative 75 percent by 2009 . A very gradual increase occurred in 2010 and 2011, particularly for multifamily units, but the 2011 level of starts per 1,000 people was still 72 percent below the 2005 level.

At first glance, the level of housing starts per 1,000 people at the peak in 2005 does not appear to be particularly high, especially when compared

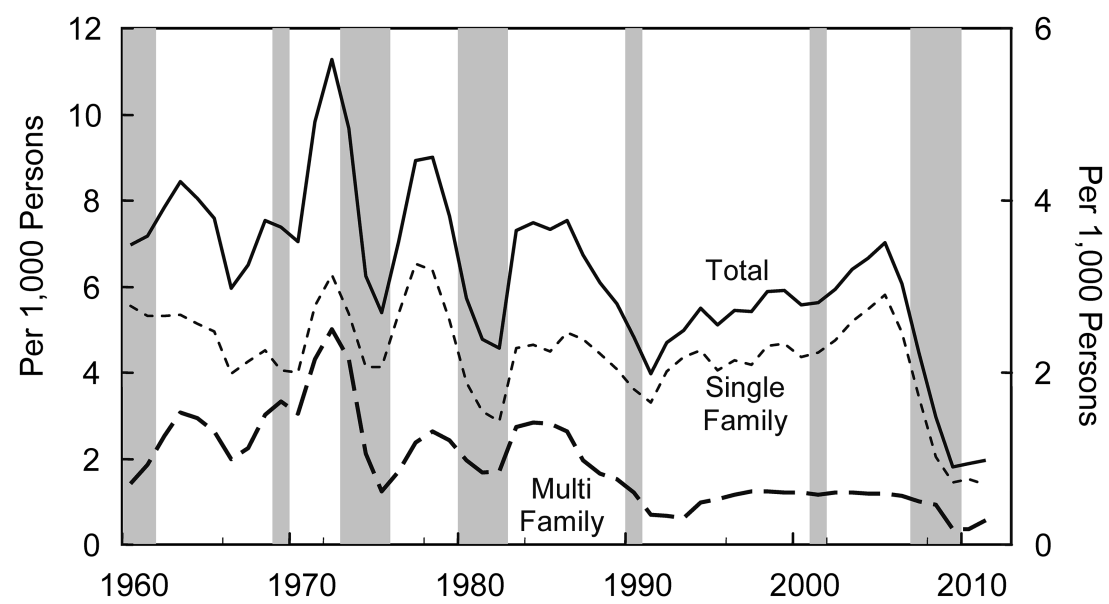

Fig. 2.2 Single and multifamily housing starts over total population

Source: Census Bureau.

Note: Shading reflects NBER recessions. 


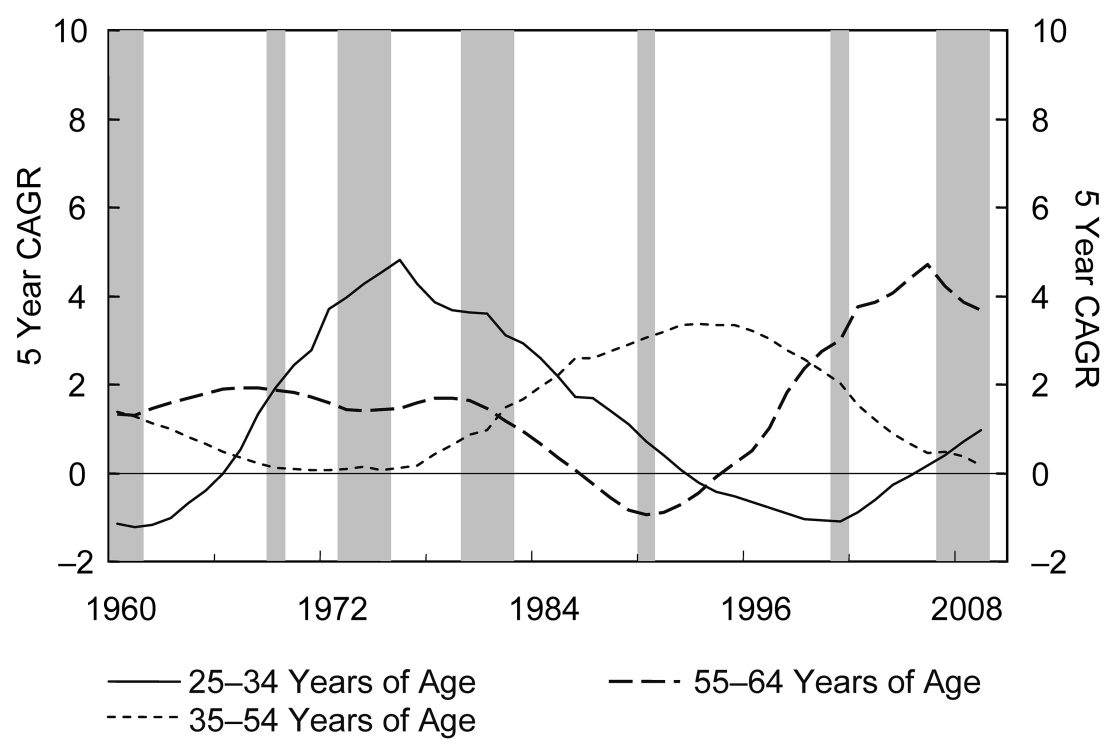

Fig. 2.3 Population growth by age cohort

Source: Census Bureau.

Note: Shading reflects NBER recessions.

to what occurred in the 1960s and 1970s. However, the underlying demographic conditions of the country were fundamentally different in these two periods. These underlying demographic dynamics can have important long-term impacts on the level of demand for housing (Mankiw and Weil 1989). As shown in figure 2.3, up until the mid-1970s, the number of people in the twenty-five to thirty-four year age group (the post World War II baby boom) was growing very rapidly. People at this stage of the life cycle tend to establish independent households for the first time such that the headship rate for this age group is quite a bit higher than for people under twentyfive years of age (figure 2.4). In the second half of the 1970s, the number of people in the thirty-five to fifty-four age group, whose headship rate makes another distinct jump upward, began to increase rapidly. These age-specific population growth rates, along with some increase in age-specific headship rates, resulted in a rising aggregate headship rate (figure 2.5). This meant that the demographically driven number of households was rising quite a bit faster than the underlying population.

In contrast, from the mid-1990s through the mid-2000s the number of people in the twenty-five to thirty-four year age group was actually declining, while the growth rate of those thirty-five to fifty-four years of age was slowing sharply. At the same time, the number of people aged fifty-five to sixty-four was rising rapidly. In addition, headship rates for individual age 


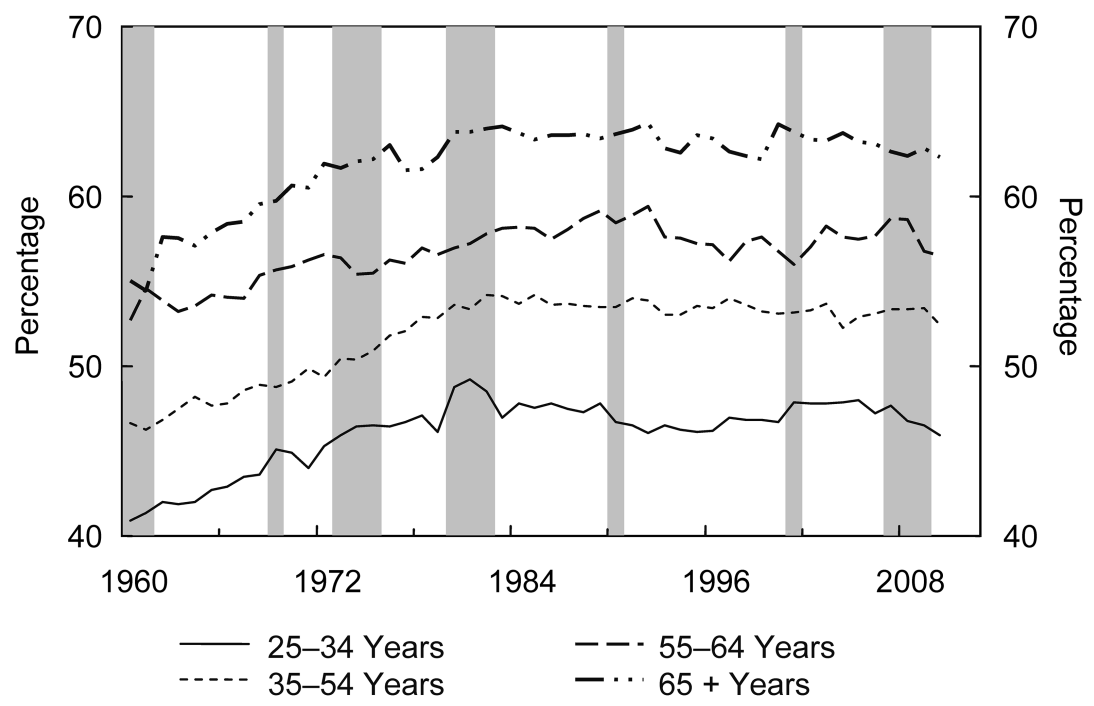

Fig. 2.4 Headship rates by age cohort Source: Census Bureau.

Note: Shading reflects NBER recessions.

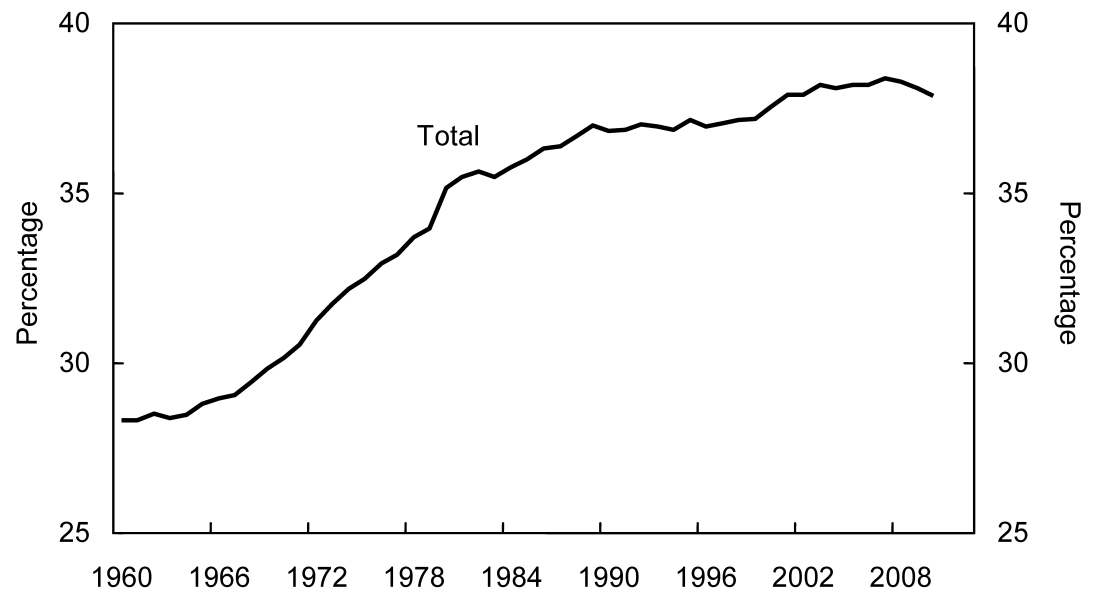

Fig. 2.5 Aggregate headship rate

Source: Census Bureau.

Note: Shading reflects NBER recessions.

cohorts generally peaked in the 1980s and have since been relatively stable to slightly declining. These factors combined to keep the overall US headship rate essentially flat since the mid-1980s. As a result, the underlying trend growth of the number of households was limited to the growth of the population, which was slowing rapidly from the mid-1990s onward. Thus, 


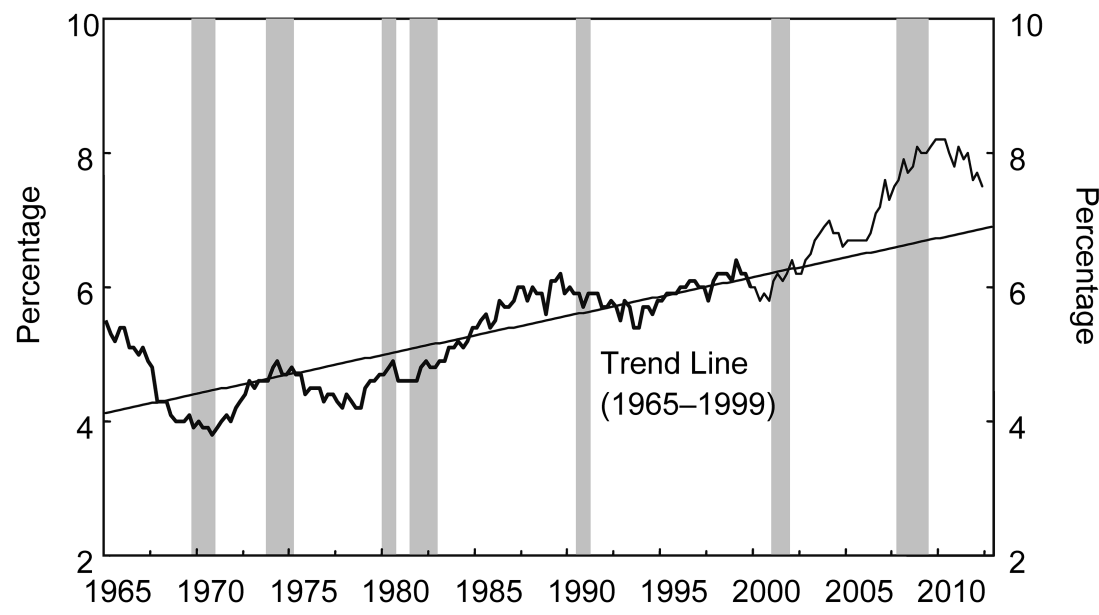

Fig. 2.6 Vacancies as a percent of total housing units (excluding seasonal vacancies)

Source: US Bureau of the Census, Housing Vacancy Survey, and authors' calculations. Note: Shading reflects NBER recessions.

referring back to figure 2.2, from a demographic perspective, housing starts per 1,000 people should have continued to trend gradually lower from the mid-1990s onward. The order of magnitude of the resulting overbuilding relative to underlying demographic trends can be estimated in different ways with different data sources. But as we shall see, the resulting estimates are roughly similar.

One approach is based on the Census Bureau's Housing Vacancy Survey. This survey provides quarterly estimates of the stock of housing and its occupancy status. Figure 2.6 presents an aggregate vacancy rate for the US housing stock based on that data. To construct this vacancy rate, the numerator is the number of units vacant for rent, vacant for sale, and units in the category "held off the market for other reasons." The number of units in this latter category has historically been quite modest and usually reflected units in the probate process. However, the number of units in this category has risen rapidly over the recent past, apparently reflecting units that have been taken back by lenders (held in their real estate owned [REO] inventory) but not yet offered for sale or rent. The denominator is the numerator plus all occupied units intended for year-round use. A trend line fitted through the time series for the period from 1965 through 1999 suggests that there has been a slight secular uptrend in this vacancy rate. Since the early 2000s the actual value has consistently been above the trend line, with the actual value peaking in 2010:Q2 and moving slightly lower since then.

Figure 2.7, which is derived from this same housing vacancy data program, presents an estimate of the number of "excess" housing units, meaning vacant units above a rough estimate of normal or equilibrium vacancies. 


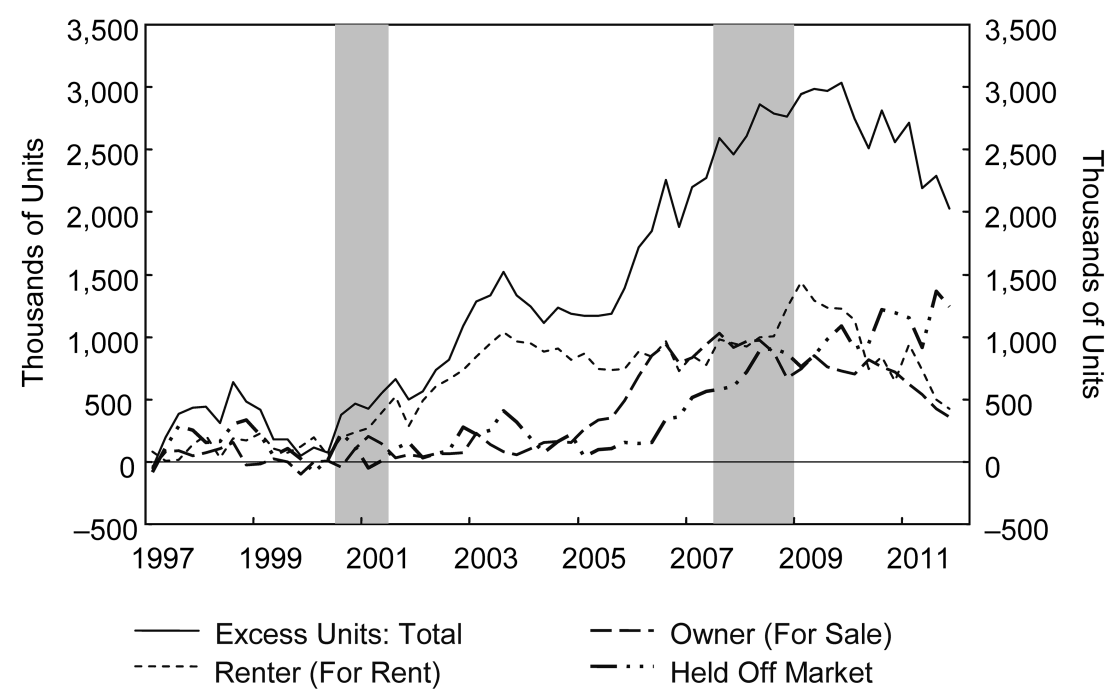

Fig. 2.7 Excess supply of housing

Source: US Bureau of the Census, Housing Vacancy Survey, and authors' calculations. Note: Shading reflects NBER recessions.

In this particular case, separate estimates of equilibrium vacancy rates are derived for single- and multifamily units for sale, single- and multifamily units for rent, and single-and multifamily units held off the market for other reasons. Excess units are defined as units in each of these six categories above the number of units implied by the equilibrium vacancy rates. The estimate of the number of excess units peaked at around 3 million in mid-2010, which provides a rough estimate of the amount of "overbuilding" of housing that occurred during the boom. Since then the number of excess units has been gradually declining, reaching around $21 / 4$ million by mid-2012. The number of excess units for sale and for rent has declined fairly sharply while the number of units held off the market has continued to rise.

An alternative measure of the amount of overbuilding that occurred is the difference between the cumulative sum of the number of housing units started relative to the amount of new housing units needed to meet the trend rate of growth of the number of households. Figure 2.8 provides such an estimate. Based on the rate of growth of the population and its age structure, we estimate that the trend rate of growth of households over the period since the mid-1990s is about 1.17 million per year. Due to losses from the existing stock due to fires, floods, and obsolescence, we estimate that about 1.4 million housing starts per year are needed to provide housing for the 1.17 million new households. Starting from 1995, we cumulate the number of housing starts minus 1.4 million (the solid line curve) and the change in the number of households minus 1.17 million (the dotted line curve). The 


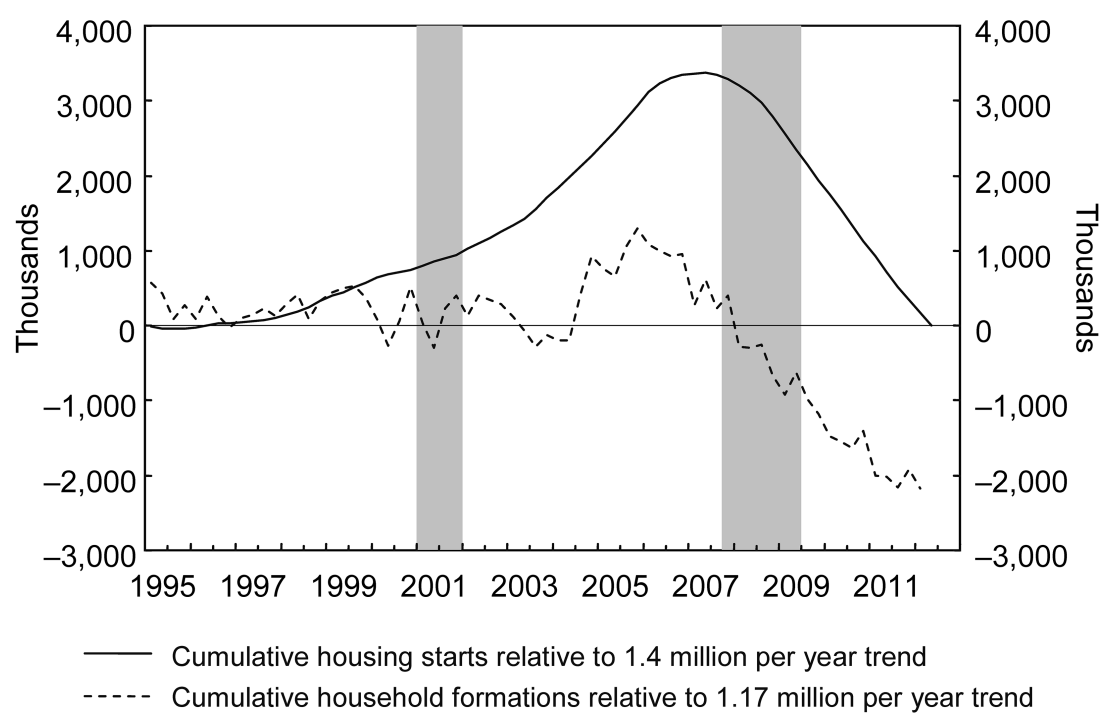

Fig. 2.8 Cumulative housing production and household formations relative to trend Source: US Bureau of the Census and authors' calculations. Note: Shading reflects NBER recessions.

difference between the two curves is an estimate of overproduction. Strictly from the standpoint of production, the maximum overbuilding was achieved in 2007:Q2 at about 3.4 million units. However, likely due to the strength of the economy and labor markets, household formations were running above trend at that point, so relative to the actual number of households the peak excess production occurred in 2009:Q1 at around 3.5 million units. In terms of both timing and number, this result is similar to that based on the vacancy data.

Figure 2.8 also provides some insight into why this most recent housing downturn has been so protracted. Since mid-2007, a period of five years, housing starts have been below the 1.4 million trend, such that as of mid2012 the excess production that began in the mid- to late 1990s has been worked off. However, due to the weakness of the economy, the rate of household formations has fallen well below trend. Thus, while from a pure production standpoint we no longer have an excess supply, vacancy rates remain above their longer run equilibrium values. Figure 2.9 provides additional insight into the issue of household formations. Not only are they running well below the demographic trend, the growth that is occurring is more than accounted for by renter households while owner households continue to decline. While still at relatively low levels, over the past year there has been a considerably larger percentage increase of multifamily housing starts than of single-family starts. 


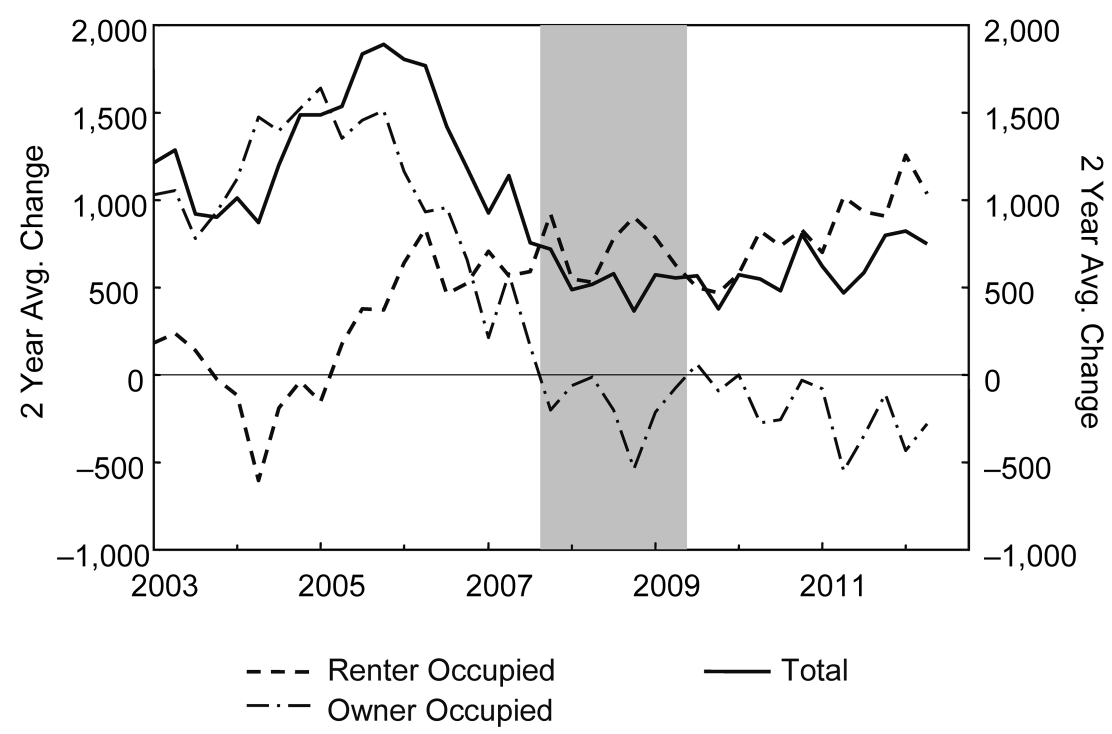

Fig. 2.9 Household formations by type

Source: US Bureau of the Census and authors' calculations.

Note: Shading reflects NBER recessions.

Table 2.1 provides some regional detail on the measure of excess housing units based on the Housing Vacancy Survey, which provides annual data for the four major census regions that corresponds to the national data that is provided on a quarterly basis. Using the same methodology as employed in the construction of figure 2.7, table 2.1 presents the regional distribution of total excess housing units in 2009 and 2011 and compares it with the regional distribution of total housing units. In 2009 the largest share of excess units was in the South, followed by the Midwest, where in both cases the share of excess units exceeded the corresponding share of the housing stock. In contrast, in the Northeast the share of excess units was roughly half its share of the total housing stock. By 2011 the picture had changed. The West's share of excess units declined significantly, the South's share declined modestly, while the shares of the Northeast and Midwest increased by about 4 and 5.5 percentage points, respectively. Of course, these changes reflect both trends in housing production and demographic trends such as relative population growth rates.

To focus specifically on the issue of excess production and where it occurred, figure 2.10 presents a scatter plot of combinations of population growth and housing starts per 1,000 people for each of the individual states. Each of the black dots in the chart represents population growth (expressed at a compound annual rate) over the period from 1990 to 2000 and the average level of housing starts per 1,000 people over the same time period for each of the fifty states. Note the fairly tight positive relationship 
Table 2.1

Shares of excess housing vacancies by region

\begin{tabular}{lccccc}
\hline & \multicolumn{2}{c}{2009} & & \multicolumn{2}{c}{2011} \\
\cline { 2 - 3 } \cline { 5 - 6 } & Share of stock & $\begin{array}{c}\text { Share of } \\
\text { excess units }\end{array}$ & & Share of stock & $\begin{array}{c}\text { Share of } \\
\text { excess units }\end{array}$ \\
\hline Northeast & 18.0 & 9.4 & & 17.9 & 13.3 \\
Midwest & 22.4 & 26.1 & & 22.3 & 31.5 \\
South & 37.9 & 43.9 & & 38.0 & 42.0 \\
West & 21.7 & 20.6 & & 21.7 & 13.2 \\
Total & 100.0 & 100.0 & 100.0 & 100.0 \\
\hline
\end{tabular}

Source: Authors' calculations based on Housing Vacancy Survey data.

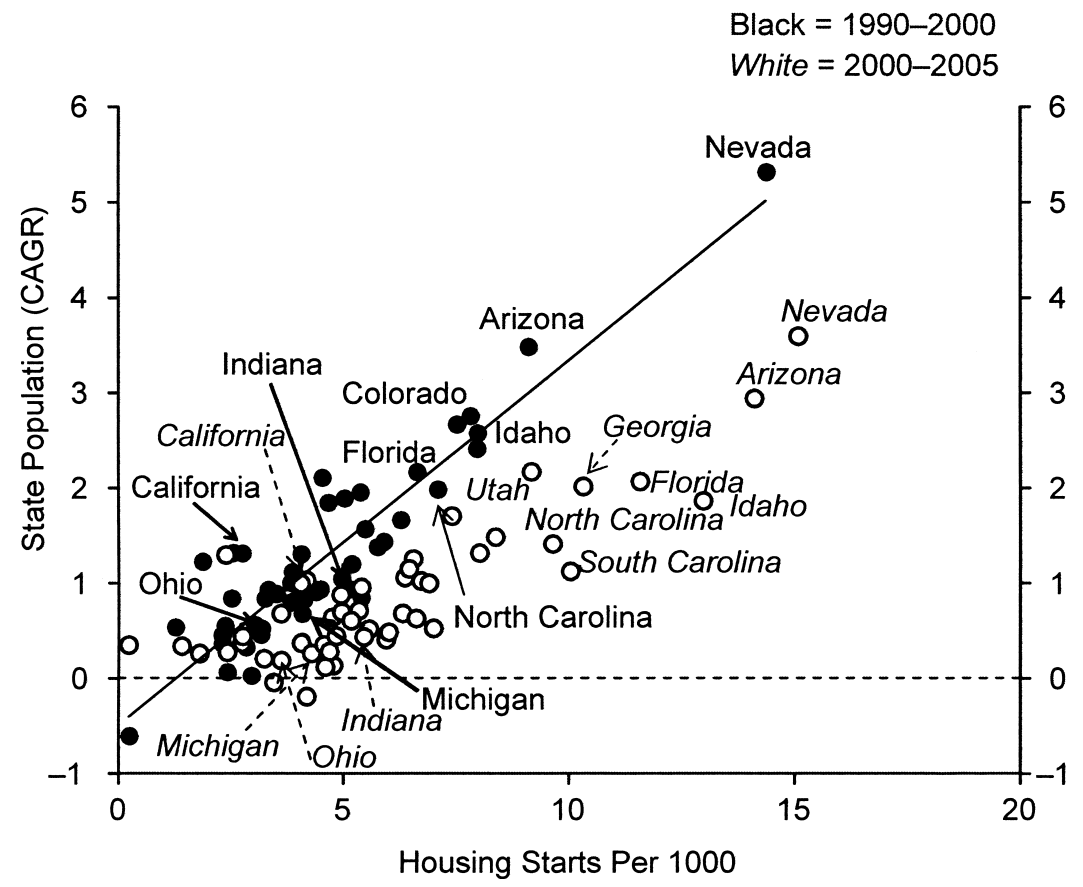

Fig. 2.10 Population growth versus housing starts

indicated by the close clustering of the black dots relative to the regression line. Focusing on this period, the supply side of the housing market showed a tremendous ability to scale production rates to a wide variation in local population growth rates. There is no evidence that housing supply lagged population growth by any significant degree even in the fastest growing states such as Arizona and Nevada. ${ }^{5}$

5. If there were significant costs of adjustment to housing supply, this might show up as the black dots associated with the fast-growing markets tending to be to the left of the regression line. 
The white dots in figure 2.10 represent the combinations of population growth rates and housing starts per 1,000 people for each state over the period from 2000 to 2005 . Note that virtually all states moved to the right relative to the earlier decade, meaning an increase in housing starts for a given population growth rate. That is, the housing boom from a supply perspective was to a degree a national phenomenon. The magnitude of shift, however, tended to be larger for those states that experienced above-average population growth in the 1990s. This can be seen for three of the four "sand states." The population growth rate in Florida was fairly constant relative to the 1990s, while the rate of housing supply per capita nearly doubled. Arizona experienced a slight slowing in its population growth rate, but like Florida its rate of housing supply per capita increased significantly, growing by roughly a third. Unlike the other sand states, Nevada experienced a significant slowdown in its rate of population growth. However, the rate of housing supply in Nevada in 2000 to 2005 did not respond to this slowdown, resulting in Nevada's white dot being significantly to the right of the regression line. ${ }^{7}$ Three other states that stand out in figure 2.10 in terms of a high rate of housing construction relative to population growth are Georgia, North Carolina, and South Carolina. The fact that housing supply increased relatively the most in these three states as well as the sand states may reflect that home builders were producing a product geared toward people at the later stages of their careers who might have been looking for a second home or a retirement home. ${ }^{8}$

Figure 2.11 addresses the issue of how these increases in housing production during the 2000 to 2005 period are related to available measures of the elasticity of supply of new housing. On the horizontal axis of the chart we measure for each state the percentage distance of the 2000 to 2005 housing starts per 1,000 people from the value predicted by the regression line of the 1990 to 2000 period given the 2000 to 2005 rate of population growth. On the vertical axis we plot elasticities of supply as estimated by Saiz (2010), where all of the elasticities for the MSAs in a state were averaged to provide a state estimate. ${ }^{9}$ Also shown is a least squares regression line fitted through the scatter diagram. While there is a great deal of dispersion around that line, the upward slope is statistically significant ( $t$-statistic of 3.74). Similarly, figure 2.12 presents the relationship between that same estimate of supply elasticity and the cumulative percent change of house prices over the period

6. The "sand states" refer to Arizona, California, Florida, and Nevada.

7. California is the only sand state that did not have a population growth rate in the 1990s that exceeded the national average. California's rate of housing supply in the 1990s was not significantly higher than what would be predicted from the regression relationship. During the boom, California's rate of housing supply did increase, but this increase only moved it to the regression line and not to the right of the regression line.

8. It should be noted, however, that housing starts are not necessarily the same as net additions to the stock of housing due to destruction and demolition of existing units.

9. Note that North Dakota was dropped from this diagram as it represented an extreme value for percentage difference from the regression line. 


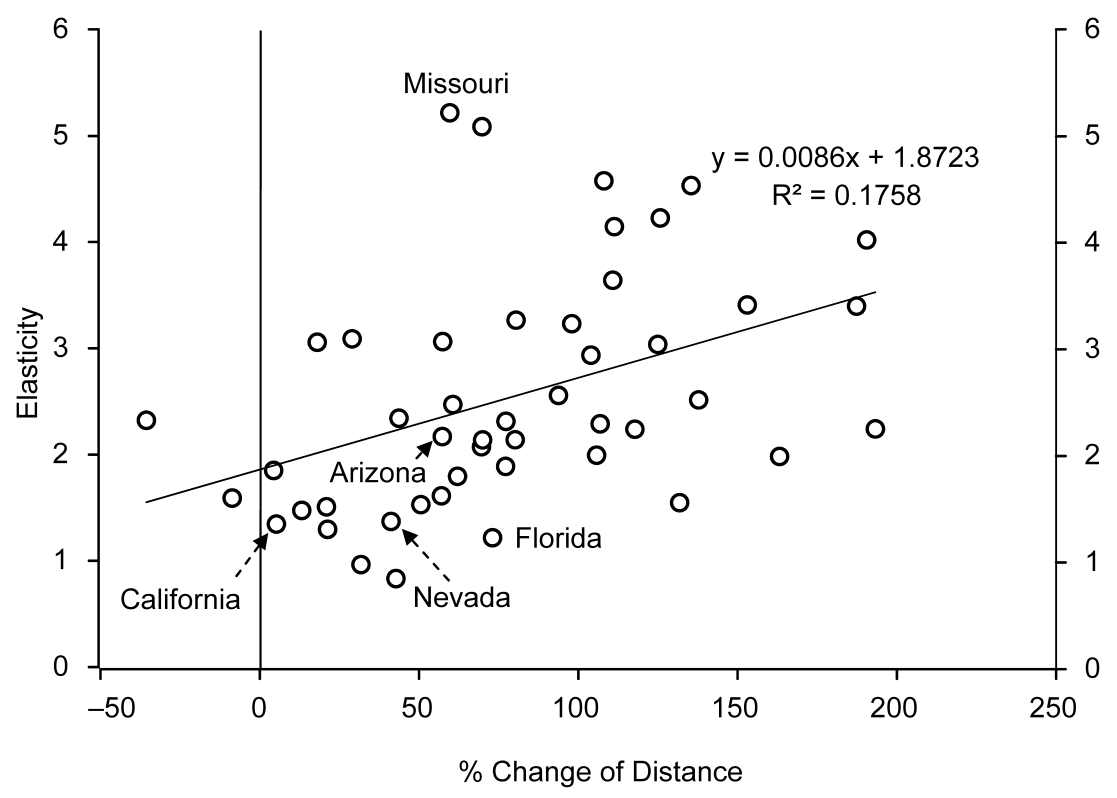

Fig. 2.11 Elasticity versus percent distance, 1990-2000 trend Note: North Dakota excluded as outlier.

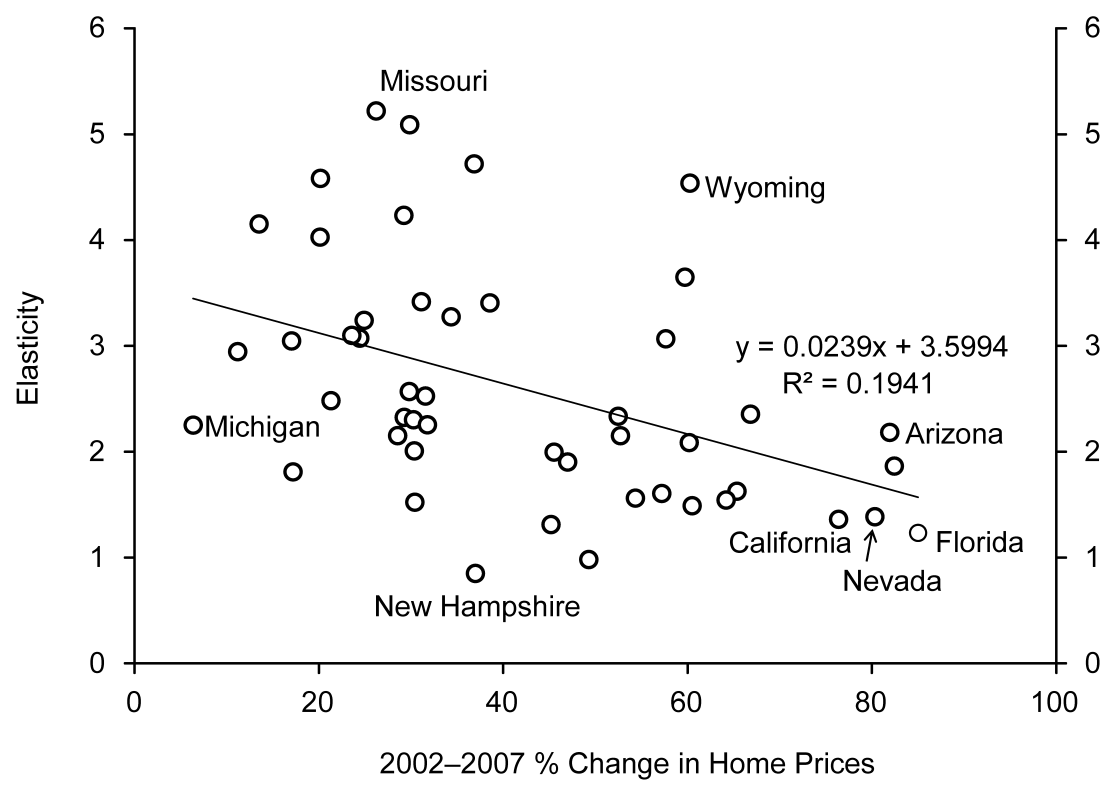

Fig. 2.12 Elasticity versus change in home prices 
from 2002 to 2007. In this case the negative slope of the regression line is statically significant ( $t$-statistic of -3.33$)$.

\subsection{Trends in Size, Amenities, and Quality}

New homes produced for sale have been getting larger, with more bedrooms, bathrooms, and garages, for quite some time. Figure 2.13 presents the median size of new homes sold, measured in square feet, for the period from 1978 through $2011 .{ }^{10} \mathrm{~A}$ trend line was fitted through the series for the period from 1978 through 1998, with that trend then extended from 1999 to 2011. While the median square footage in 2005 is 3.3 percent above that trend, that represents just 1.2 standard deviations of the residual of the estimated trend line, suggesting that the 2005 value is not significantly above what would be suggested by the established trend. Figure 2.14 presents the median size of the lot that the structure was built upon, also measured in square feet. Again, a trend line was fitted through the data for the period from 1976 to 1998 and then extended over the period from 1999 to 2011. Clearly, average lot size declined during the building boom years. The median lot size in 2004 was 8.3 percent below the estimated trend. Combined, the two trends indicate that during the boom years of the 2000s builders were economizing on the amount of land devoted to each unit, likely reflecting the fact that land prices were rising relatively rapidly. However, due to the wide variation in the median lot size over the period from 1976 to 1998 , that 8.3 percent represents just 1.2 standard deviations of the residual of the estimated trend line. Note that the decline in median lot size from the mid-1990s through the mid-2000s was due in part to a modest increase of the share of units that were attached as opposed to detached. But the median lot size of attached units declined in a similar fashion.

Of course, changes in physical characteristics such as square footage and number of bathrooms do not capture changes in quality, such as the materials used and the level of skill and care employed in construction. It is certainly conceivable that as demand for new homes intensified, the quality of new homes, defined in this manner, slipped somewhat. To shed some light on this issue, we used American Housing Survey (AHS) data to estimate the percentage premium that home buyers place on new homes versus existing homes. All else equal, a new home is likely to command a premium as it is likely to require lower maintenance expenditures over an expected holding period. By estimating that premium for AHS surveys before and during the construction boom, we can observe how that premium changed over time.

The estimation procedure was as follows. From each AHS data set from 1985 through 2007 we create a sample of owner-occupied single-family homes purchased over the two-year period since the preceding AHS. The

10. These data are from the "Characteristics of New Homes Sold," which is part of the Census Bureau's statistical program called "New Residential Sales." 


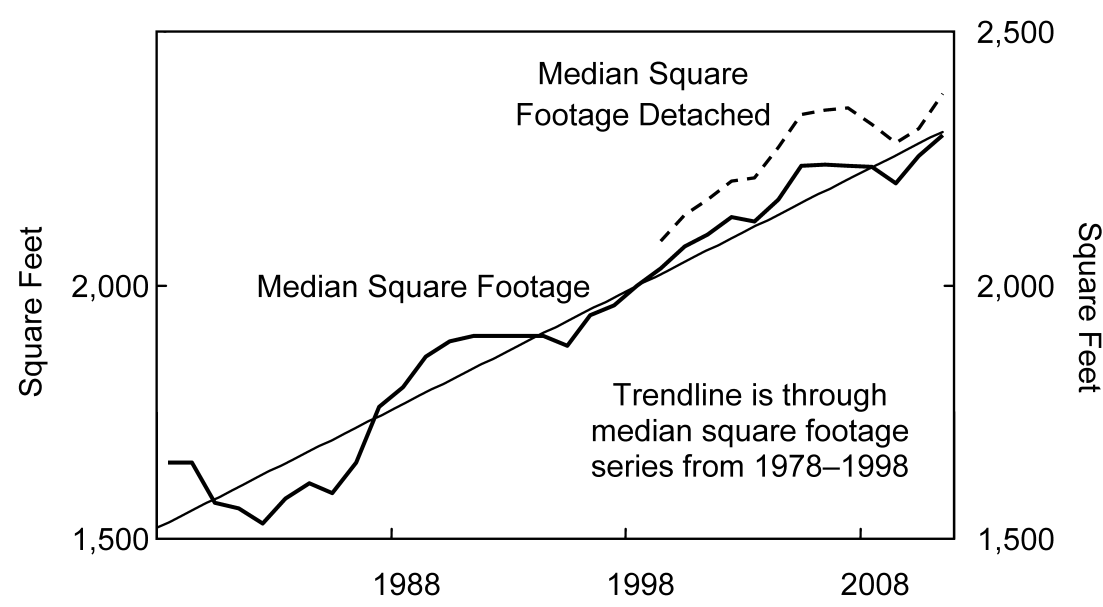

Fig. 2.13 Median square footage of new homes sold

Source: Census Bureau.

Note: Shading reflects NBER recessions.

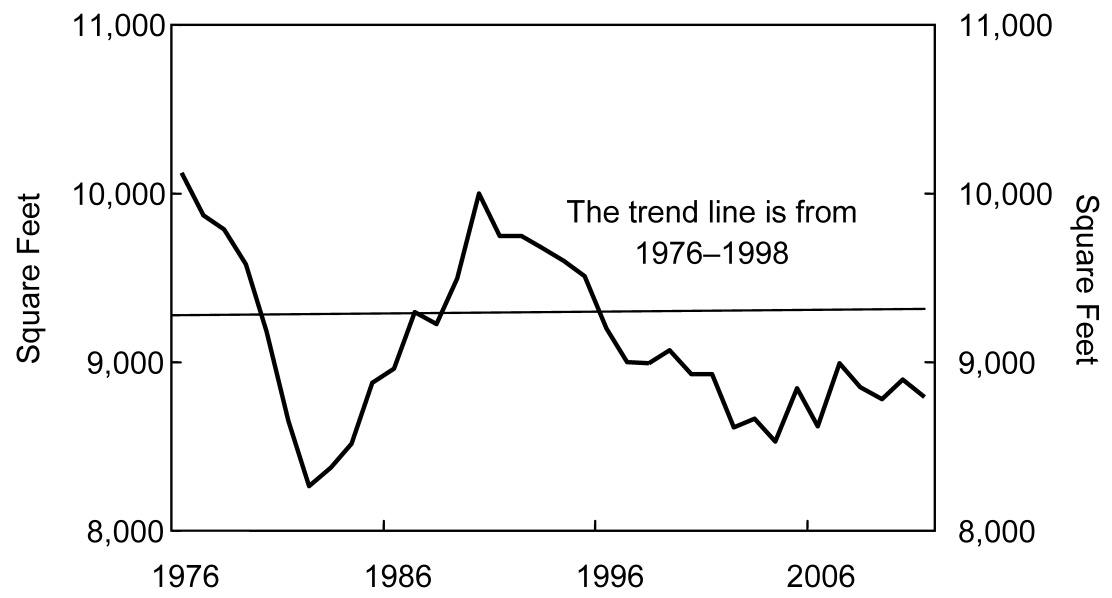

Fig. 2.14 Median lot size

Source: Census Bureau.

sample sizes range from a high of around 1,200 in 1995, of which roughly 20 percent were new homes, to a low of around 500 in 2007, of which 10 percent were new homes. We then estimate a hedonic regression of the log of the self-reported value of that home on a series of physical characteristics such as unit square footage, size of the lot, number of bedrooms, number of bathrooms, and so forth. We used as a guide for this regression the procedure used by the US Bureau of the Census in the construction of its constantquality new home price series. We add to that procedure a dummy variable 


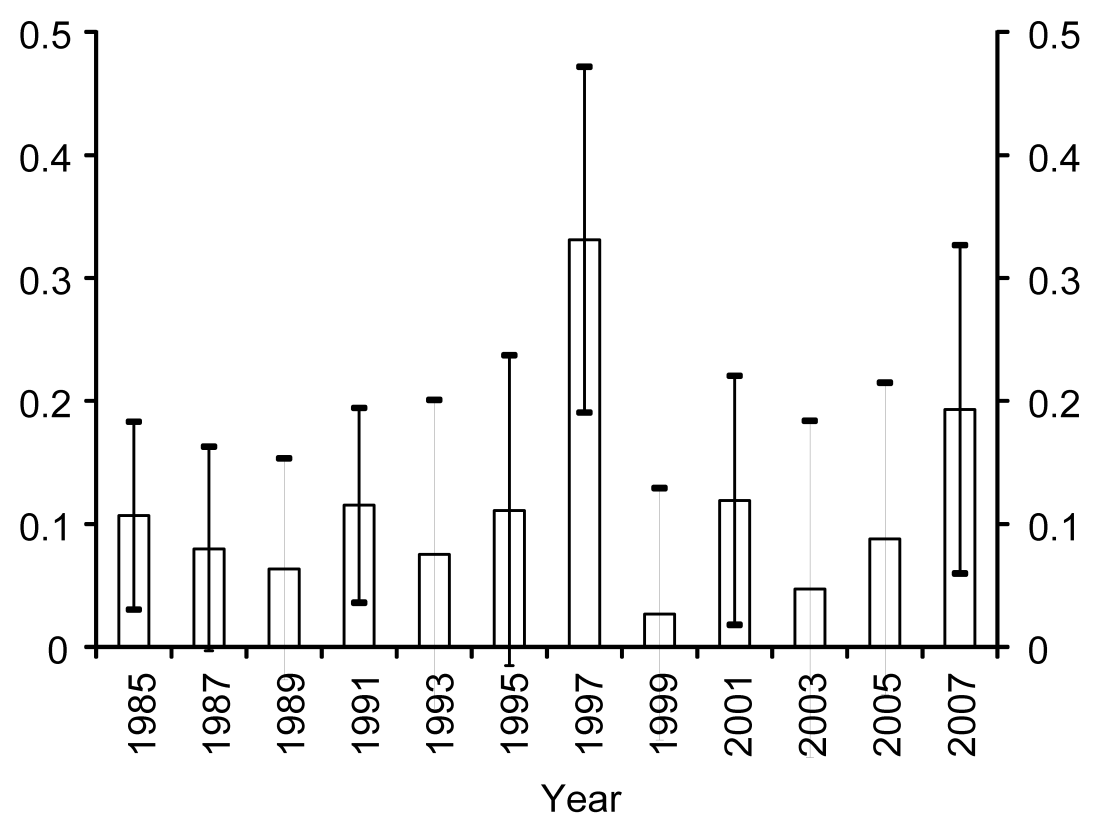

Fig. 2.15 The percent premium for a new home Source: AHS.

for the purchase of a new home (defined as being built in the last two years) rather than an existing home. In addition, all regression include Standard Metropolitan Statistical Area (SMSA) fixed effects to control for any composition shifts in where new homes were being constructed over time.

Figure 2.15 presents the estimated new home premium for AHS years from 1985 through 2007. The black dashes above and below each estimate represent 90 percent confidence intervals. In seven of the twelve cases, that confidence internal includes zero. Given the volatility of the estimated premium and the rather wide confidence bands around the estimates, it does not appear that there was a systematic change in the premium during the period from the early 2000 s through 2005 relative to what is was prior to and after that period.

\subsection{Trends in the Home Building Industry}

The home building industry has traditionally been characterized as having relatively low barriers to entry such that there are a large number of firms producing a relatively few number of units per year. Indeed, 79 percent of the builder members of the National Association of Home Builders started ten or fewer homes in 2010. However, a characteristic of the housing boom from the early 1990s through the mid-2000s is the pronounced growth of market share of a relatively few number of firms, the bulk of which were 


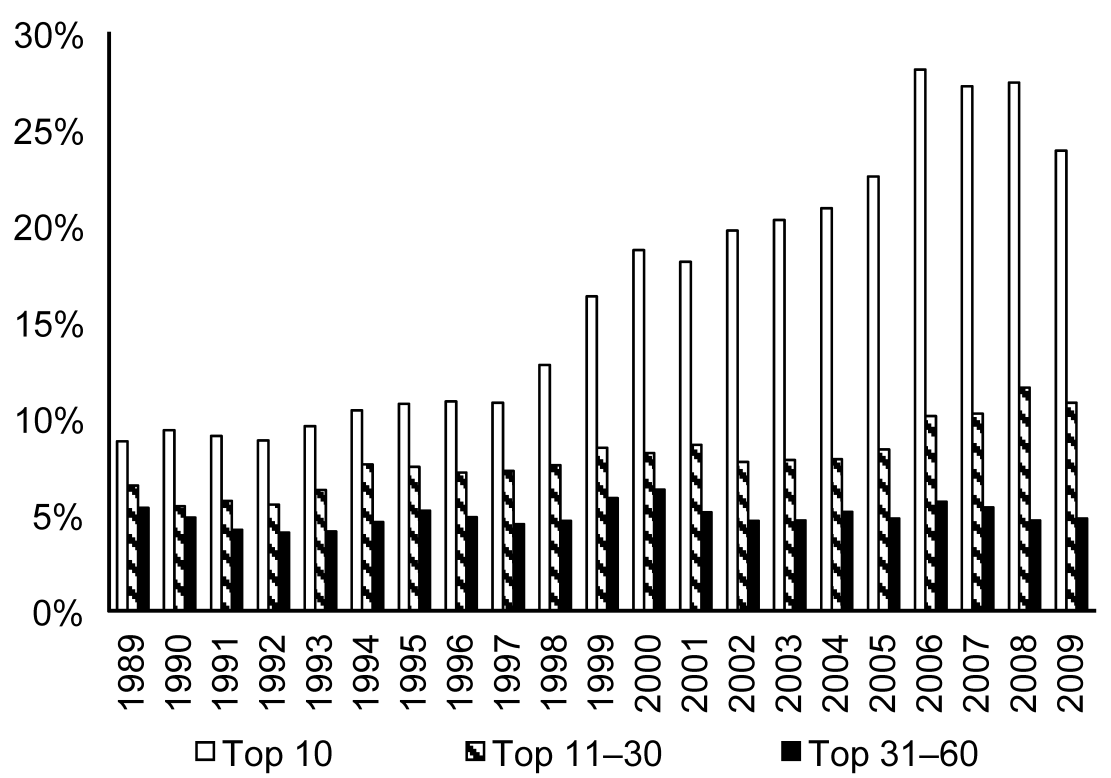

Fig. 2.16 Share of new home sales by size of home builder Source: Builder Magazine, Census Bureau.

publicly owned and, to a large extent, financed directly through capital markets rather than financial intermediaries such as banks. This consolidation within the building industry has been discussed by others (see Ambrose 2009, 2010 and Frey 2003). Following, we update some of this prior analysis. In addition, we explore whether any excess returns were higher during the height of the housing boom. Finally, we look at whether the capital markets provided more timely signals than the banking industry for builders to start to reduce their activity levels.

Figure 2.16 provides a time series of the share of new home sales accounted for by the top ten to top sixty builders by size. In 1990 the top sixty builders accounted for 20 percent of new home sales (as defined by the Census Bureau), while the top ten builders accounted for 9.4 percent. Over the next fifteen years there was steady consolidation in the industry, such that by 2005 the top sixty accounted for 36 percent and the top ten for 22.6 percent. For this increase in share of the top ten builders to occur, it means that these firms captured roughly one-third of the increase in sales that occurred over that period. The top sixty largest firms accounted for nearly half of the increase. It is also interesting to note that the ten largest firms experienced additional large increases in market share over the period from 2006 through 2008. However, this increase occurred when overall sales and prices were declining, and reflected the fact that the large builders had accumulated a large inventory of homes in their production pipelines.

This rapid growth by the largest builders reflected a mix of internal or 
Table 2.2

Total closings and percentage change from mergers and acquisitions

\begin{tabular}{lrrrc}
\hline Company & 1993 & 2004 & $\begin{array}{c}\text { Change } \\
1993-2004\end{array}$ & $\begin{array}{c}\text { Percent through } \\
\text { acquisition/merger }\end{array}$ \\
\hline D. R. Horton & 1,668 & 44,005 & 42,337 & 45.1 \\
Pulte Homes & 9,798 & 38,612 & 28,814 & 38.7 \\
Lennar Corp. & 4,634 & 36,204 & 31,570 & 55.7 \\
Centex Corp. & 11,685 & 32,896 & 21,211 & 15.6 \\
KB Homes & 5,982 & 26,937 & 20,955 & 63.2 \\
Beazer Homes USA & 2,496 & 16,437 & 15,921 & 72.9 \\
The Ryland Group & 8,319 & 15,101 & 6,782 & 19.9 \\
Hovnanian Enterprises & 3,671 & 14,586 & 10,915 & 105.8 \\
M.D.C. Holding & 3,344 & 13,876 & 10,532 & 20.5 \\
NVR & 4,248 & 12,749 & 8,501 & 7.0 \\
Total & 55,845 & 251,383 & 195,538 & 46.1 \\
\hline
\end{tabular}

Source: Builder Magazine, Mergers Online, and NAHB Economics. See http://mydigimag.rrd .com/publication/?i=37093\&p=61.

"organic" growth as well as growth through acquisitions. Table 2.2 shows the growth in closings by the top ten builders over the period from 1993 to 2004, and the decomposition by organic versus acquisition. For the group as a whole, 46 percent of their growth in closings over the eleven-year period leading up to the peak was due to acquisitions. As one might expect, there were multiple motivations for these acquisitions. But in conversations with leading analysts of this industry, the prime motivation appears to have been to obtain land and local expertise in promising markets.

There are several dimensions on which large and small builders differ. Small builders are to a large extent reliant on bank financing. Their ability to launch new construction projects and to continue building spec homes depends on the willingness of those banks to extend financing. The scrutiny of the builder's activities by the lender can be surprisingly intense. In contrast, large builders are much less reliant on banks, obtaining the bulk of their financing through issuance of debt and equity directly in capital markets. Thus, the ability of these large builders to expand their balance sheet is determined by the willingness of markets to advance more funds.

A second distinction is that large builders are vertically integrated from land acquisition and development, construction, marketing, and mortgage financing. This organization helps these builders exploit scale economies involved in large development projects and to have a broader source of revenues and potential profits. It is also possible that by being involved in each segment of the production and distribution chain, large builders had an informational advantage in the markets they operated in.

To shed light on these points, table 2.3 presents the balance sheet of Toll Brothers, a well-known publicly traded home builder, as of April of 2005, right around the peak of new home construction. At that time assets totaled 
$\$ 5.4$ billion, of which 80 percent was the firm's inventory of lots, homes under construction, and completed homes. Liabilities totaled $\$ 3.1$ billion, of which notes issued in the capital markets represented 43 percent. Bank financing, consisting of loans payable (the used portion of a credit line extended by a consortium of banks) and the mortgage subsidiaries warehouse line of credit, represented just 17 percent of total liabilities. The debt to equity ratio of the firm was 1.35 .

Table 2.4 shows the building lot inventory data for the top ten builders from 2002 to 2008. The lot inventory is broken down into lots that were owned by the builders, lots where the builders held options to purchase, and lots that were part of joint ventures. The last column converts the total

Table 2.3

Large home builder balance sheet

Toll Brothers Inc. and Subsidiaries as of April 30, 2005

\begin{tabular}{|c|c|c|}
\hline Assets & ( $\$$ in thousands) & $\%$ of total assets \\
\hline Cash and cash equivalents & 566,668 & 11 \\
\hline Inventory & $4,299,587$ & 80 \\
\hline \multicolumn{2}{|l|}{ Property, construction and office } & 1 \\
\hline \multicolumn{3}{|l|}{ Receivables, prepaid expenses and other } \\
\hline Mortgage loans held for sale & 78,663 & 1 \\
\hline Customer deposits held in escrow & 76,681 & 1 \\
\hline \multicolumn{2}{|l|}{ Investment in and advances to } & 2 \\
\hline Total assets & $5,351,453$ & 100 \\
\hline \multicolumn{2}{|l|}{ Liabilities } & $\%$ of total liabilities \\
\hline Loans payable & 358,922 & 12 \\
\hline Senior notes & 845,914 & 28 \\
\hline Senior subordinated notes & 450,000 & 15 \\
\hline Mortgage company warehouse loan & 69,108 & 2 \\
\hline Customer deposits & 389,265 & 13 \\
\hline Accounts payable & 202,918 & 7 \\
\hline Accrued expenses & 611,340 & 20 \\
\hline Income taxes payable & 147,964 & 5 \\
\hline Total liabilities & $3,075,431$ & 100 \\
\hline \multicolumn{3}{|l|}{ Equity } \\
\hline Common stock & 776 & \\
\hline Additional paid in capital & 251,646 & \\
\hline Retained earnings & $2,051,056$ & \\
\hline Unearned compensation & $(834)$ & \\
\hline Treasury stock & $(26,622)$ & \\
\hline Total Equity & $2,276,022$ & \\
\hline
\end{tabular}




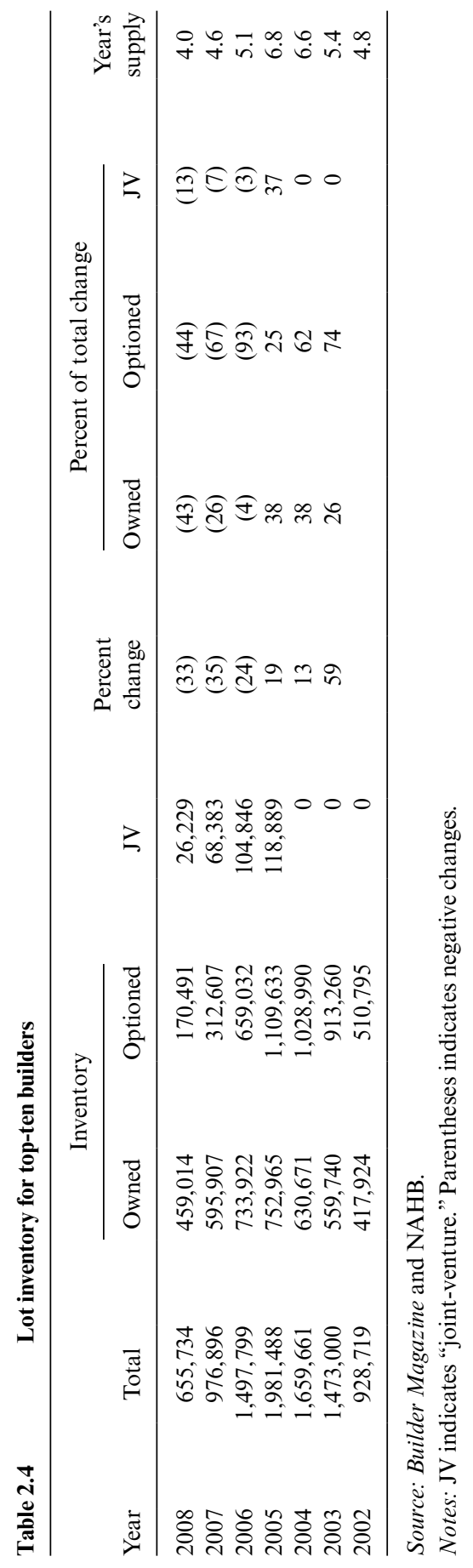


inventory into a year's supply at the prevailing sales rate. The first thing to note is that the inventory of lots grew quite rapidly over the period from 2002 to 2005, suggesting that these builders remained quite optimistic about future sales prospects even as the market was approaching its peak. Indeed, in terms of years' supply the builders were substantially lengthening their investment in land, from 5.4 years in 2003 to 6.8 in 2005.

As we know now, single-family housing starts peaked in 2005:Q3 and home prices peaked roughly one year later. It appears that the top ten builders responded aggressively to this turn of events. From 2005 to 2006, the largest builders reduced their lot inventory by 24 percent. Almost all of this reduction, 97 percent, was through the lots that they held options on. Options continued to be the dominant adjustment mechanism as well in 2007, with 67 percent of the shrinkage accounted for by optioned lots. It is not until 2008 that the adjustment process is roughly balanced between percentage reductions in owned and optioned lots. Note, however, that lots are only one portion of a builder's inventory. While we do not have data on homes either under construction or completed for these large builders, the macro data indicate that it took quite a bit longer to reduce inventories in those categories.

Another feature of the increase in housing production from the mid1990s through the mid-2000s was that an increasing share of single-family units was "built for sale" (figure 2.17). Built for sale, sometimes referred to as a "spec" or speculative start, refers to situations where the land and structure are sold in one transaction. An example is when a home builder develops a section of land, putting in roads and utilities, and then begins selling indi-

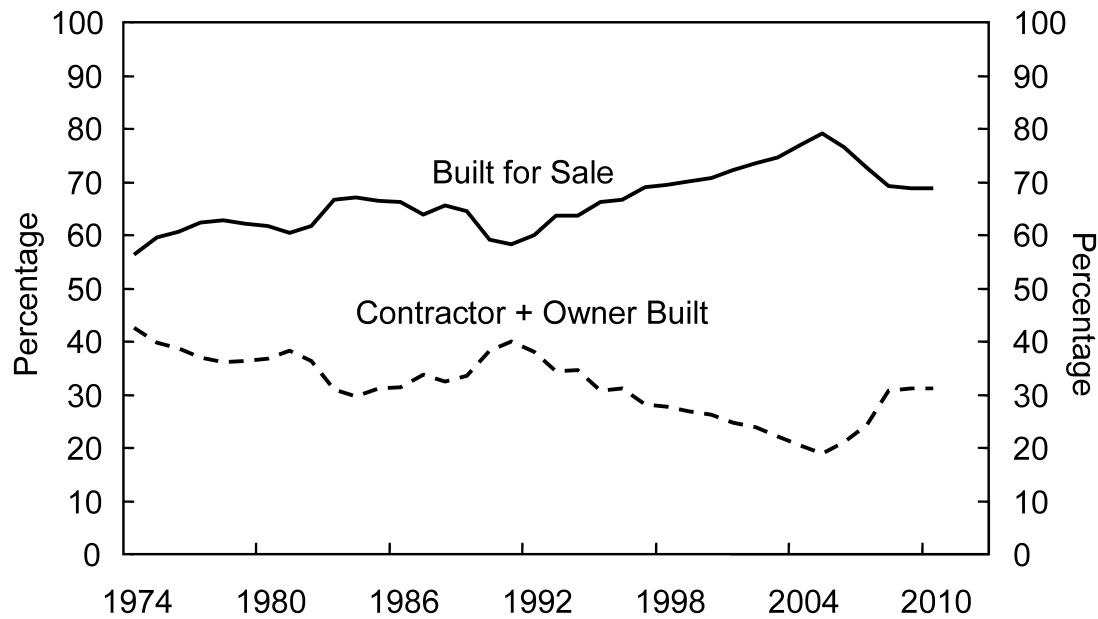

Fig. 2.17 Share of new single-family homes completed built for sale Source: Census Bureau. 


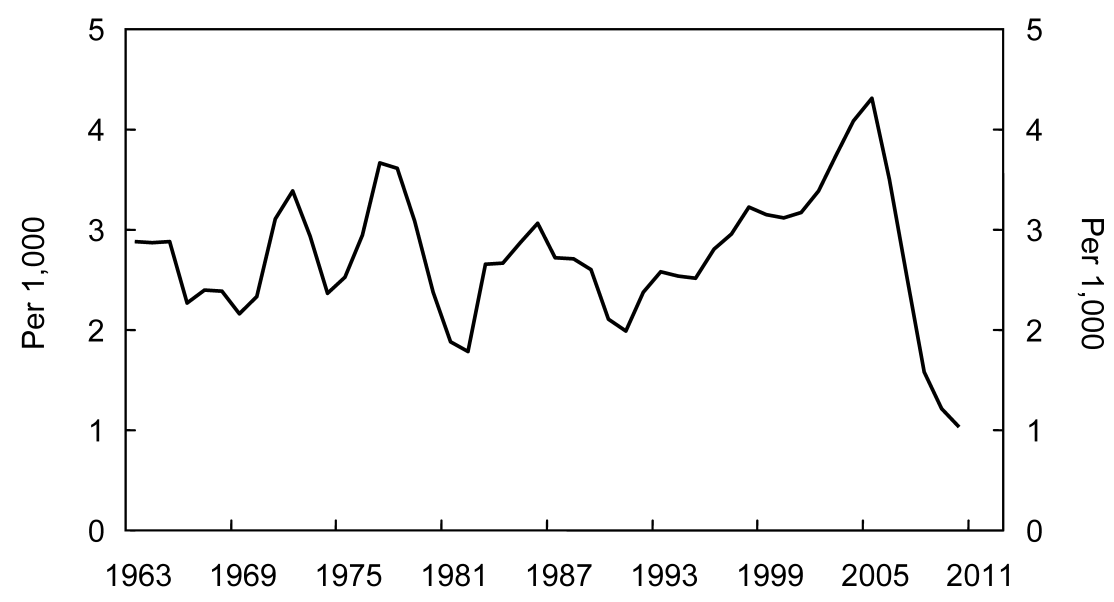

Fig. 2.18 New single-family homes sold per 1,000 people

Source: Census Bureau.

vidual lots with houses - either already completed, under construction, or not yet started. In contrast, contractor- or owner-built units are cases in which an individual or firm already owns the land and either hires a general contractor or acts as their own general contractor. ${ }^{11}$ Monthly data on sales of new single-family homes refers only to sales of "spec" units, and the sale can occur at various stages - completed, under construction, or even not started. Due to the shift toward construction of single-family units, and the shift toward speculative units within the single-family market, sales of new single-family homes per 1,000 people in 2005 reached the highest of the entire period for which there is data (dating back to 1963) (figure 2.18).

The shift toward more speculative building also meant that even though new housing starts declined abruptly and remain quite low to this day, the home building industry ended up with a large inventory of units in their production pipeline that took quite some time to unwind. Figure 2.19 presents the inventory of new single-family homes for sale broken down into the categories of not started, under construction, and completed. As house prices peaked in many markets in early 2006, builders began to reduce their units not started and under construction. The pace of contraction was faster in units under construction, which may reflect the continuing option value of keeping improved lots on hand in case markets stabilized. Completed units did not reach their peak until late 2007, nearly a year and a half after the slowdown was under way in units under construction. The inventory of

11. It is also the case that an increasing share of multifamily starts were built for sale, likely as condominiums, as opposed for the rental market. 


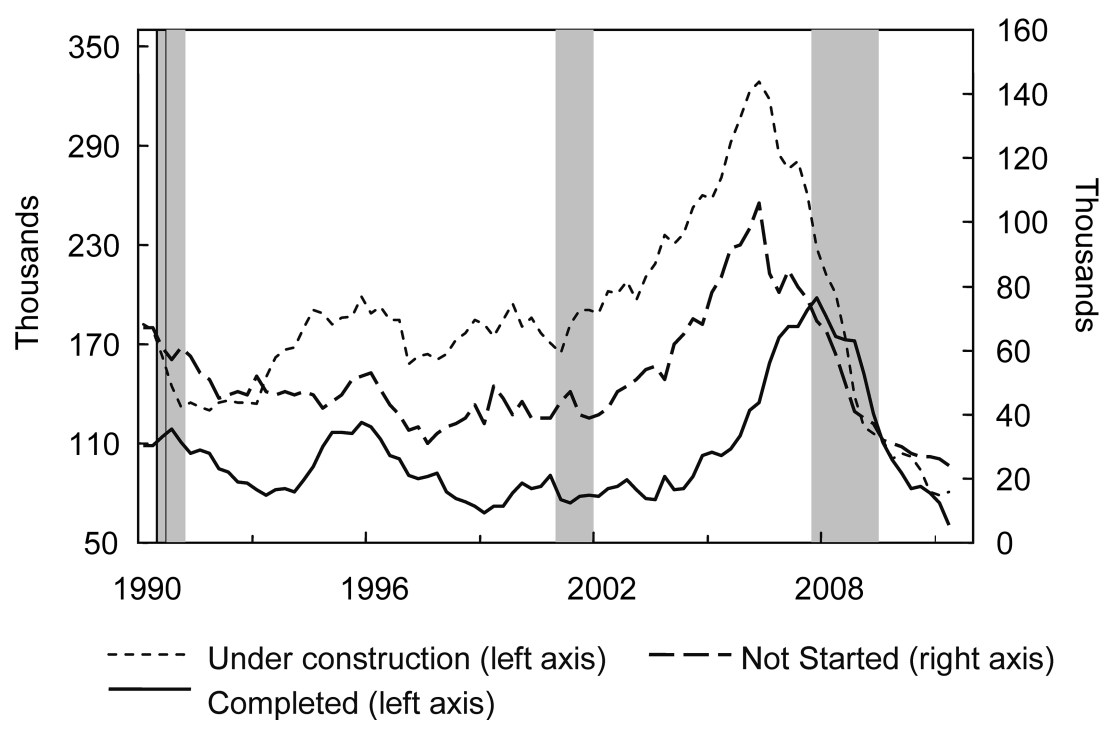

Fig. 2.19 New single-family homes for sale by stage of completion

Source: US Bureau of the Census.

Note: Shading reflects NBER recessions.

completed units for sale has only recently returned to levels that prevailed prior to the boom. A question that we will return to is whether builders were too slow to respond to changing demand conditions in their respective markets, contributing to an excess of housing inventory.

This review of the macro data and the data on individual firms in the home builder industry suggests that one of the reasons the housing downturn has been so severe and so prolonged is the industry, particularly the largest firms, built up such substantial inventories of lots and homes at various stages of production. As the largest firms tend to obtain financing from capital markets rather than banks, an interesting question is whether the capital markets were providing any early indications that this inventory represented a significant downside risk to their earning should demand turn out to be weaker than expected. In figure 2.20 we compare a fixed weighted index of the equity prices for six large home builders and the Federal Reserve's Senior Loan Officer Opinion Survey (SLOOS) data on lending standards for mortgage loans. ${ }^{12}$ For the SLOOS, values above (below) zero indicate that standards

12. In order to create the fixed weight equity index, we collected Bloomberg's market capitalization and equity time series for a subset of home builders. Specifically, we selected home builders that had a large market presence before the housing bust and are still in operation today. The home builders in our equity index are: Toll Brothers Inc., Pulte Group Inc., Lennar Corp., DR Horton Inc., Hovnanian Enterprises Inc., and Beazer Homes USA Inc. Keeping 


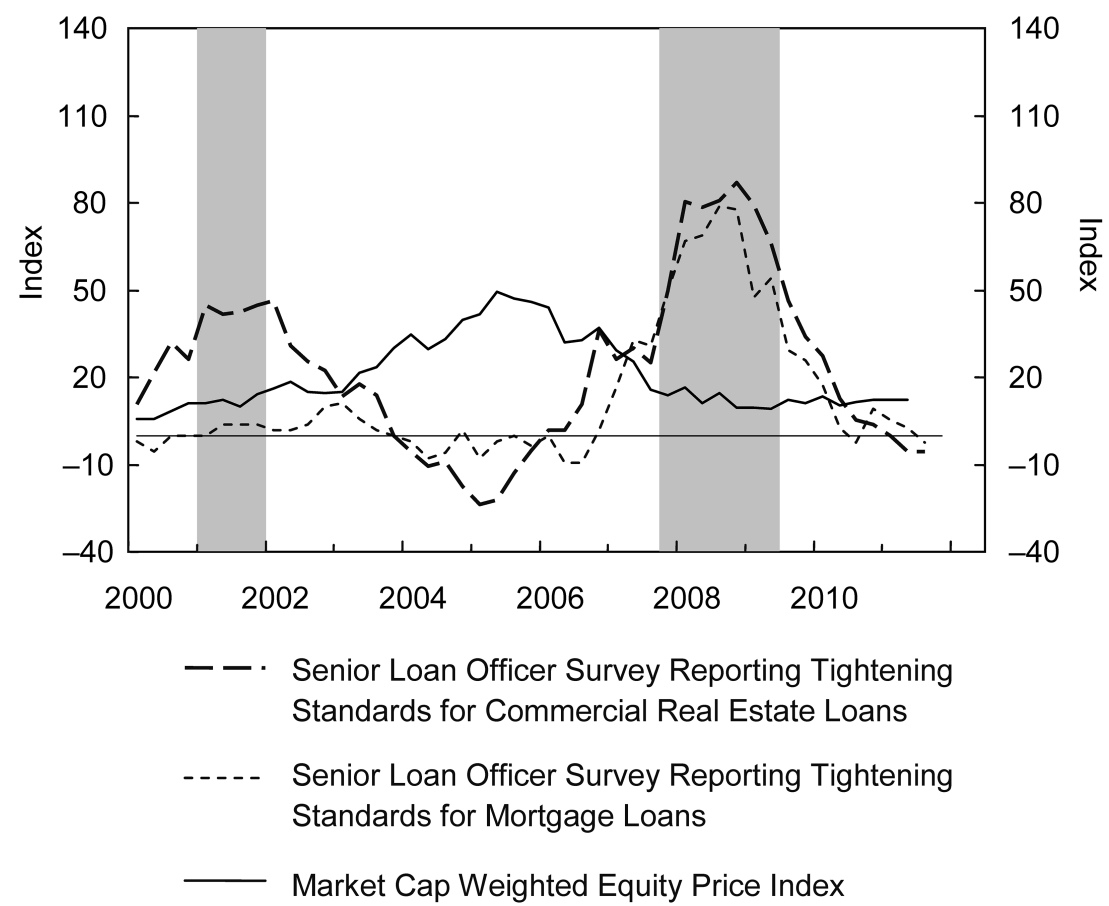

Fig. 2.20 Equity price index and various measures of the SLOOS

Source: WRDS, Bloomberg, and authors' calculations.

Note: Shading reflects NBER recessions. The weight used in the equity price index is the market capitalization at the peak of the housing starts series for each security in the index.

on net are reported to be tighter (looser) since the prior survey. We can see that bank lending standards were being loosened from 2004 to mid-2006. The SLOOS indicates that lending standards began to tighten in the fourth quarter of 2006. In contrast, the home builder equity price index peaks in August 2005, more than a year earlier than the onset of tightening by banks. By the end of the third quarter of 2006, the home builder equity price index had declined by 45 percent. Figure 2.21 summarizes analyst equity recommendations for the major builders. Again, we see a sharp drop-off in "buy" recommendations in the third quarter of 2005 matched by a pickup in "sell" recommendations. Finally, figure 2.22 shows a market capitalization weighted average of short interest in the major builders. This series picks up in the second quarter of 2006. While the SLOOS data is not a perfect measure of when banks would have been tightening their lending to small

the market capitalization fixed at Q1:2006, the quarter in which housing starts peaked, we then created a market capitalization weighted average of the quarterly equity prices of each home builder. The resulting series was then indexed to equal 100 for the first quarter of 2006. 
Peak of Housing Starts January 2006

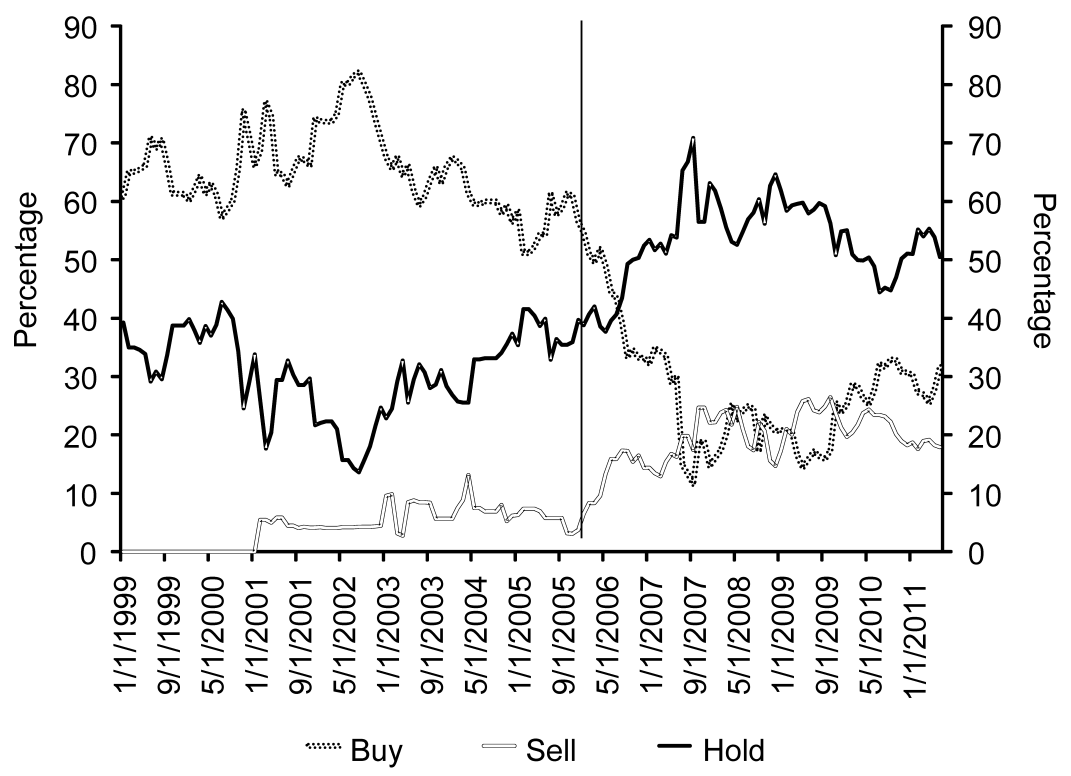

Fig. 2.21 Equally weighted analyst equity recommendations Source: WRDS.

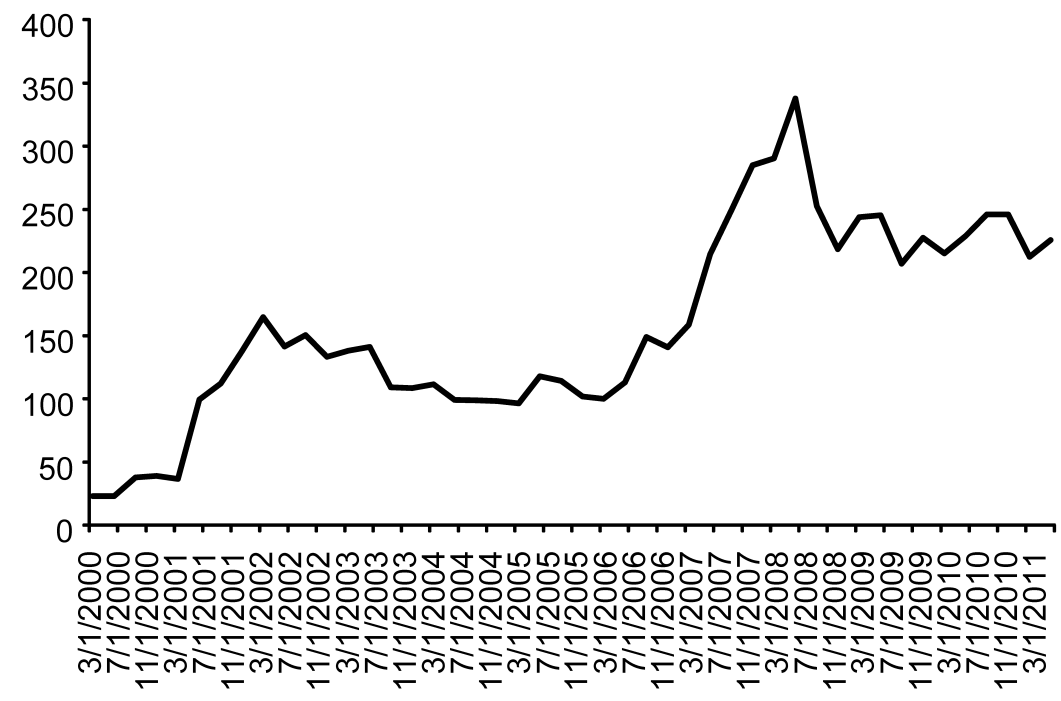

Fig. 2.22 Market capitalization weighted home builder short interest Source: Bloomberg and authors' calculations.

Notes: Index $=100$ at the peak of housing starts Q1:2006. Market capitalizations are contemporaneous to the short interest data. 
builders, these comparisons suggests that the capital markets did provide the large builders with a substantially earlier signal to pull back than the small builders likely received from their banks. ${ }^{13}$

\subsection{Land Markets during the Boom and Bust}

Builders' use of vacant lot inventories, whether owned outright or optioned, suggests an important role for vacant land as a potential driver of builder costs, and ultimately house prices. In addition to the cost and access to capital just discussed, the cost of building a new home consists of construction labor and material costs, along with the cost of developable land. Davis and Heathcote (2007) and Davis and Palumbo (2008) estimate the value of residential land nationally and in metropolitan areas, respectively, using a combination of the cost of construction and the value of housing in place. Davis and his coauthors conclude that the value of land rose sharply in the United States during the housing boom, particularly in metro areas that experienced the largest house price booms.

Given the prominent role that land inventories played on builders' balance sheets during the 2000s housing cycle, we supplement the Davis analysis with information from vacant land transactions for select metropolitan areas. Vacant land may exhibit different dynamics from land with a housing unit already in place, since the latter reflects the value of the particular structure present, as we argued earlier and as shown in figure 2.1. In addition, our data allow a parcel-level analysis of the evolving prices and quantities as well as the features of vacant land that was selling in the metro areas for which we have data.

Our land sales data come from the COMPS data set produced by the CoStar Group. Residential land sales - as opposed to other real estate transactions - are distinguished by the buyer's intention, as reported to CoStar, to use the land for construction of residential units, rather than to build other types of projects or to use structures currently present. Figures 2.23 and 2.24 display the residential land price indexes and log number of acres sold in eight Metropolitan Statistical Areas (MSAs) with inelastic and elastic housing supplies, respectively, as estimated by Saiz (2010). For comparison purposes, CoreLogic's overall House Price Indexes (HPIs) for each MSA are reported as well. ${ }^{14}$ Several features of the land sales data are noteworthy.

First is the amount of acreage transacted over time and space. In the figures, the bars show the four-quarter moving average of the natural log of acres sold. ${ }^{15}$ Perhaps unsurprisingly, the great majority of land sold for resi-

13. It is interesting to note, however, that smaller builders apparently were not caught with such large inventories of homes under construction or already completed.

14. In the case of South Florida, we use the Miami MSA HPI.

15 . We use natural logs because a few markets completely dominate the acreage calculations; plotting acreage itself with consistent axes yields figures that are hard to see in comparison with Atlanta and especially Phoenix. 

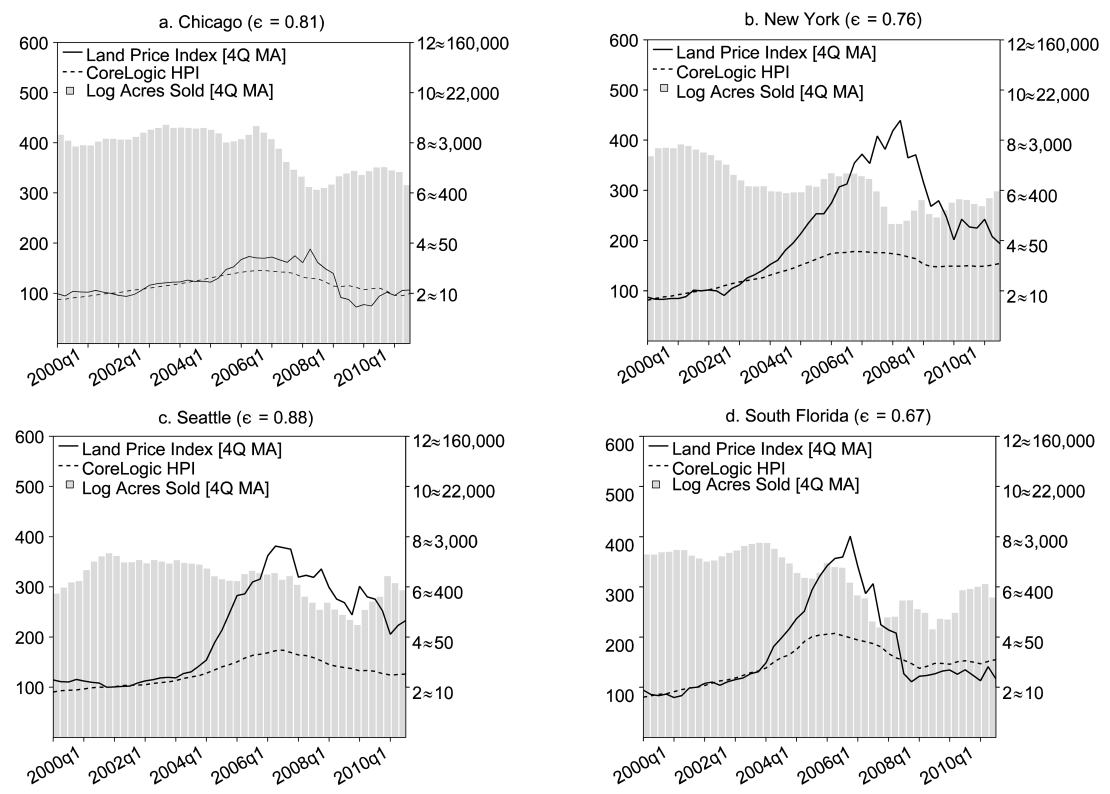

Fig. 2.23 Land prices in select markets with relatively inelastic supply

Sources: CoreLogic, CoStar, authors' calculations. Elasticity estimates from Saiz (2010).

Note: Acreage, right scale; land and house price indexes, left. South Florida comprises the Miami, Fort Lauderdale, and West Palm Beach MSAs.
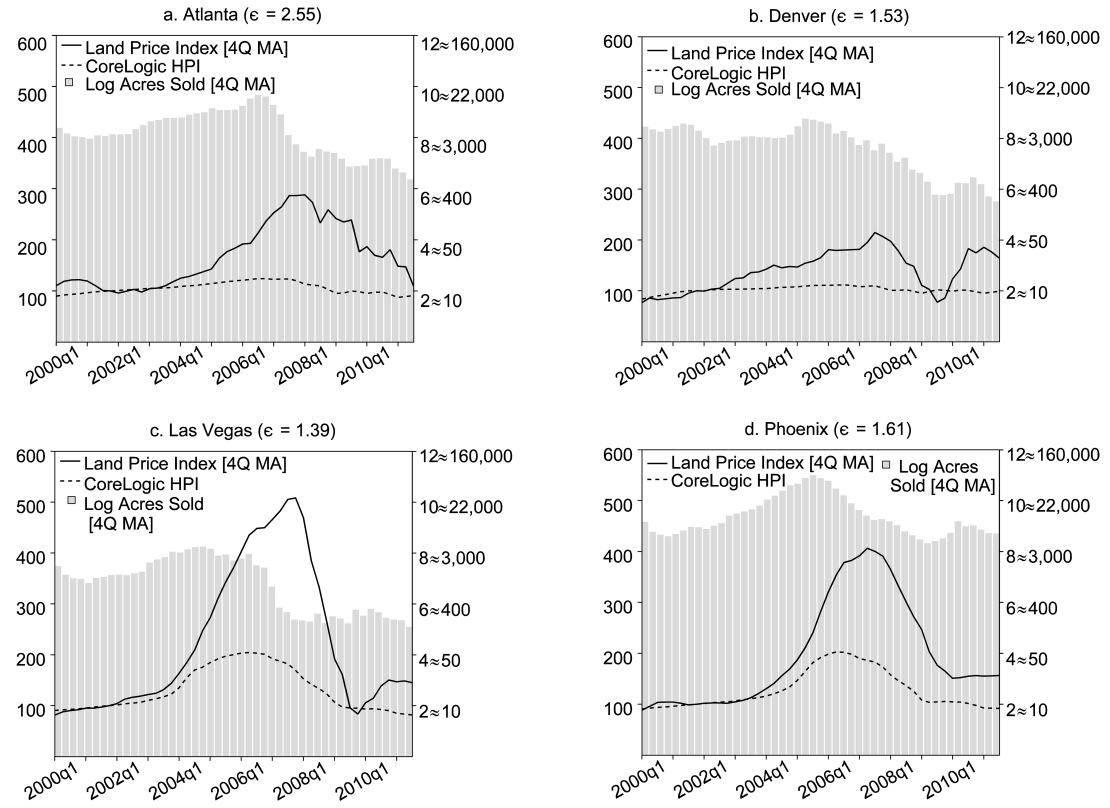

\section{Fig. 2.24 Land prices in select markets with relatively elastic supply}

Sources: CoreLogic, CoStar, authors' calculations. Elasticity estimates from Saiz (2010). Note: Acreage, right scale; land and house price indexes, left. 
dential development came from the more elastically-supplied MSAs (figure 2.24). In those cities, particularly Atlanta and Phoenix, quarterly sales of 10,000 to 20,000 acres of land for residential development were common throughout the boom. During 2005, CoStar reported average quarterly land transactions in Phoenix alone that exceeded 50,000 acres. In inelastically supplied cities like Chicago, peak land sales were closer to 3,000 acres a quarter. Land sales volumes in all cities track house prices relatively closely and began to fall quickly after the HPI peaks.

Also shown in figures 2.23 and 2.24 are land price indexes. In order to abstract from changes in the mix of properties being sold over time, we create a quarterly price index that controls for such traits as location, presence of a structure, level of preparation for building, and characteristics of the transaction. The index we employ here is interpretable as the price paid in a standard arms-length transaction for an unimproved square foot of centrally-located residential land relative to some benchmark period (2001:Q4) for that city. ${ }^{16}$

Land prices exhibit some interesting dynamics in these cities. First, as expected given relatively steady increases in building costs during the boom, raw land price increases frequently outstripped house price increases. In constrained markets like New York, Seattle, and South Florida, vacant land prices tripled or quadrupled during the boom, as theory would predict. However, perhaps as evidence of housing prices that were straying from fundamentals, even elastic markets experienced rapid price appreciation during the housing boom. In Denver, for example, raw land prices doubled between late 2001 and the end of 2006; in Las Vegas they quintupled.

Land prices in elastic and inelastic markets are more distinguished by their tendencies during the bust, from 2007 to 2010, as anticipated by our discussion of figure 2.1. In cities with elastic housing supplies (figure 2.24) nominal prices reversed course soon, although not immediately, after the housing market peak, and had generally reverted to their 2001 levels by the end of 2010. In cities with inelastic supply, residential land prices fell after the house price peak, but now seem to have firmed (again, in nominal terms) at levels 50 to 100 percent above their 2001 levels. South Florida, a victim of extreme overbuilding in spite of inelastic supply, is an exception. There, raw land prices are currently about where they were in 2001.

The price dynamics shown in figures 2.23 and 2.24 control for property location, but, like most other information on housing prices, are calculated at the MSA level, making it difficult to determine the price dynamics at different points in the metropolitan landscape. Our data, however, allow a

16. Haughwout, Orr, and Bedoll (2008) describe the development of the land price index for one of the sample cities, New York; other cities' indexes are constructed similarly. To control for the influence of outliers, the indexes are constructed from a trimmed sample, excluding the 1 percent of transactions with the highest and lowest actual prices per square foot. Indexes are smoothed using a four-quarter moving average. 
Residential land price dynamics across the metropolitan landscape

\begin{tabular}{|c|c|c|c|c|c|c|}
\hline \multirow[b]{2}{*}{ City } & \multicolumn{3}{|c|}{ Boom, 2000-2006 } & \multicolumn{3}{|c|}{ Bust, 2007-2010 } \\
\hline & $\begin{array}{c}\text { Inner } \\
25 \%\end{array}$ & $\begin{array}{c}\text { Middle } \\
50 \%\end{array}$ & $\begin{array}{c}\text { Outer } \\
25 \%\end{array}$ & $\begin{array}{c}\text { Inner } \\
25 \%\end{array}$ & $\begin{array}{l}\text { Middle } \\
50 \%\end{array}$ & $\begin{array}{c}\text { Outer } \\
25 \%\end{array}$ \\
\hline Atlanta & $6.4 \%$ & $13.4 \%$ & $17.0 \%$ & $-14.1 \%$ & $-2.3 \%$ & $-10.8 \%$ \\
\hline Chicago & 7.9 & 8.6 & 11.6 & 0.1 & 4.3 & -21.9 \\
\hline Denver & 5.2 & 14.6 & 19.8 & 2.4 & -4.8 & 4.0 \\
\hline LA Basin & 21.5 & 18.4 & 19.5 & -10.8 & -17.2 & -8.2 \\
\hline Las Vegas & 26.2 & 31.3 & 28.5 & -29.5 & -28.7 & -19.2 \\
\hline New York & 22.9 & 24.9 & 22.2 & -14.6 & -13.7 & -10.4 \\
\hline Orlando & 17.7 & 21.8 & 11.2 & -26.9 & -8.2 & 26.0 \\
\hline Philadelphia & 18.4 & 7.0 & 15.7 & 5.2 & 2.2 & 2.8 \\
\hline Phoenix & 19.1 & 22.6 & 50.5 & -11.7 & -19.1 & -27.3 \\
\hline Portland & 17.7 & 9.9 & 16.9 & -10.0 & -5.0 & -20.2 \\
\hline Seattle & 12.4 & 18.6 & 13.2 & -10.5 & -7.5 & -1.7 \\
\hline South Florida & 20.5 & 25.9 & 29.3 & -25.5 & -16.2 & -31.6 \\
\hline Tampa & 26.4 & 26.4 & 24.3 & -14.4 & 8.2 & 15.3 \\
\hline Tucson & 15.6 & 16.7 & 20.6 & -2.4 & -4.0 & -0.7 \\
\hline Washington & 20.0 & 1.6 & 16.3 & -13.9 & 19.4 & 19.4 \\
\hline $\begin{array}{l}\text { Unwtd. mean } \\
\text { across cities }\end{array}$ & 17.2 & 17.4 & 21.1 & -11.8 & -6.2 & -5.6 \\
\hline $\begin{array}{l}\text { Unwtd. std. dev. } \\
\text { across cities }\end{array}$ & 6.6 & 8.3 & 9.8 & 10.3 & 12.0 & 17.2 \\
\hline
\end{tabular}

Source: CoStar Group; authors' calculations.

Note: Figures in the table are compound average annual growth rates for the specified periods.

finer look at the geography of the land boom and bust, and table 2.5 reports these results for fifteen large cities. In each city, a measure of the center is created - typically the tallest building — and land transactions are grouped according to whether they are among the 25 percent (of plots sold) in closest proximity to the center, the 25 percent farthest from the center, or the middle 50 percent.

The mean figures, reported at the bottom of the table, reflect some general tendencies across the cities: during the boom (2000 to 2006) prices rose in all parts of the average metropolitan area; in the bust they fell in all parts. Generally speaking, the boom was the strongest on the fringe, and the bust was weakest there as well. Thus the housing cycle of the 2000s was associated with a flattening of the price gradient in these metros.

But the overall data mask substantial heterogeneity, as the large standard deviations indicate. In some cities-Atlanta, Denver, Phoenix, South Florida - the boom was noticeably concentrated on the fringe. In others, particularly supply-constrained cities like New York, Los Angeles, and Seattle, land prices in the center more or less kept pace with price changes on the fringe, leaving the gradient either unchanged or, in some cases, steeper. 


\subsection{Who Got the Profits-Builders or Landowners?}

As noted earlier, the large builders likely benefited from scale economies in terms of lower material costs, cheaper funding, and greater production efficiencies. An important question is whether the combination of consolidation among the largest builders and a housing boom led to large builders earning excess returns. To explore this question, we created a monthly equity returns series for publicly traded builders. In each month, we calculate the market capitalization-weighted average equity return by month. Our data runs from January 1990 to May 2012. We then disaggregate this equity return series into a series for the top-ten builders based on market capitalization in each month, and a series of the non-top ten builders. ${ }^{17}$ We estimate simple market models by regressing the builder monthly equity return on a market return. We use the Russell 2000 Index as our market return.

The market model results are presented in table 2.6. Specifications (1) and (2) report results for the overall builder equity returns, while specifications (3) and (4) focus on the non-top-ten builders, and specifications (5) and (6) focus on the top-ten builders. Two things stand out from specification (1). First, the building industry as a whole does not display any higher or lower cyclicality than does the overall market. The estimated beta for the industry is equal to one. Second, for the more than twenty years covered by the data, the building industry earned an average annual excess return of 20 percent. ${ }^{18}$ Specification (2) checks to see if the excess returns to the building industry changed during the height of the housing boom. The data indicate that outside of the period from January 2000 to June 2005 the building industry earned on average an annualized excess return of 13 percent. ${ }^{19}$ However, during the housing boom the average annualized excess return increased significantly to 48 percent.

Both the large average excess returns overall and the significant increase in these excess returns during the housing boom raise the question of to what extent these excess returns were going to all publicly traded builders or only the largest of the firms. To explore this we turn to our disaggregated return series. Specifications (3) and (4) report results for the non-top-ten builders. The data indicate that outside of the period of the housing boom, the non-top-ten builders did not earn on average any excess returns. However, during the housing boom, they earned average excess returns of 43 percent. In addition, while the overall building industry has a market beta of one, the non-top-ten builders have a market beta of 1.4 , which is statistically higher than one. In contrast, looking at specifications (5) and (6), which focus just

17. Over the period the top-ten builders accounted for between 80 to 95 percent of the total market capitalization of all publicly-traded builders.

18. The annualized compound excess return is given by $(1.01573)^{\wedge} 12-1$.

19. June 2005 was the peak of the home builders' sentiment series collected by the National Association of Home Builders. 
Market model estimates for building industry stock returns

\begin{tabular}{|c|c|c|c|c|c|c|}
\hline & \multicolumn{2}{|c|}{ All public builders } & \multicolumn{2}{|c|}{ Non-top-ten builders } & \multicolumn{2}{|c|}{ Top-ten builders } \\
\hline & (1) & (2) & (3) & (4) & (5) & (6) \\
\hline Alpha & $\begin{array}{l}1.573 * * \\
(0.382)\end{array}$ & $\begin{array}{l}0.996^{* *} \\
(0.434)\end{array}$ & $\begin{array}{c}0.747 \\
(0.639)\end{array}$ & $\begin{array}{c}-0.004 \\
(0.730)\end{array}$ & $\begin{array}{l}1.625^{* *} \\
(0.392)\end{array}$ & $\begin{array}{l}1.066^{* *} \\
(0.446)\end{array}$ \\
\hline $\begin{array}{l}\text { Alpha } \\
\text { interaction } \\
(1 / 00-6 / 05)\end{array}$ & & $\begin{array}{l}2.346^{* *} \\
(0.871)\end{array}$ & & $\begin{array}{l}3.058 * * \\
(1.467)\end{array}$ & & $\begin{array}{l}2.278^{* *} \\
(0.895)\end{array}$ \\
\hline Beta & $\begin{array}{l}1.001^{* *} \\
(0.066)\end{array}$ & $\begin{array}{l}1.004^{* *} \\
(0.066)\end{array}$ & $\begin{array}{l}1.399 * * \\
(0.111)\end{array}$ & $\begin{array}{l}1.404^{* *} \\
(0.111)\end{array}$ & $\begin{array}{l}0.979 * * \\
(0.068)\end{array}$ & $\begin{array}{c}0.982 * * \\
(0.067)\end{array}$ \\
\hline
\end{tabular}

Notes: Market model regresses the monthly capitalization weighted stock market returns for publicly traded builders $\left(r_{b t}\right)$ on the monthly returns for the Russell 2000 Index $\left(r_{m t}\right)$. The estimation period is from January 1990 to May 2012. A unit change is 1 percent. Coefficient estimates are given with standard errors in parentheses. Top-ten builders are based on market capitalization in each month. Market model reported in specifications (1), (3), and (5) is given by: $r_{b t}=\alpha+\beta r_{m t}+\varepsilon_{t}$, where $\varepsilon_{t}$ is the excess return in month $t$. The expanded market model reported in specifications (2), (4), and (6) is given by: $r_{b t}=\alpha+\alpha_{I} I_{1 / 00-6 / 05}+$ $\beta r_{m t}+\varepsilon_{t}$, where $I_{1 / 00-6 / 05}$ is an indicator variable that takes a value of one over the period from January 2000 to June 2005.

**Significant at the 5 percent level.

on the returns for the top-ten builders, the data indicate that they earned on average excess returns of 14 percent outside of the housing boom period, and that these average excess returns increased to 48 percent during the boom - only slightly higher than for the non-top-ten builders.

\subsection{Conclusion}

Our description of the supply side of the housing boom and bust cycle of the 2000s reveals many changes in the structure and costs of the homebuilding industry. Many of these developments might have been expected to provide some cushion against the possibility that the housing market would stray far above fundamental valuations for an extended period. The increased concentration of the industry in the decade leading up to the boom meant that large shares of the market were held by large firms with substantial market information. In addition, these firms' reliance on deep public capital markets, rather than special arrangements with individual financial intermediaries, brought with it close investor and analyst scrutiny of the marketplace and firms' positions and strategies. Smaller builders could easily observe the actions taken by the large builders operating in their markets and to free ride on the market information available to the larger builders. Furthermore, the use of land options by large builders allowed them, if market conditions changed, to exit projects before purchasing land and embarking on difficult-to-reverse building projects. The concentration of new building activity in fast-growing, supply elastic markets in areas like 
Phoenix and Las Vegas meant that new housing should have helped to limit and then to offset price increases that were originally driven by demand shifts.

Were a housing expert to be told only of these developments, without knowing what actually transpired in the housing market during the 2000s, he might well have taken some comfort that conditions were in place to discourage a market that strayed far from fundamentals. Yet while many factors may have been expected to constrain price increases and make the supply side of the market more responsive to market conditions, as a whole they were insufficient to forestall both a bubble in prices and a significant oversupply of units. It is impossible to determine how much worse things might have been absent these supply-side developments, but it seems clear in retrospect that on their own, favorable supply-side conditions cannot be exclusively relied upon to restrain the effects of major, but temporary, demand shocks.

\section{Appendix}

\section{Sources and Definitions of Data}

The US Census Bureau is the primary source of data on both the stock of existing housing and the production of new housing. The information presented in this chapter is derived from several different Census housing data programs. The following summarizes those sources and some key definitions. The following website provides background information on the housing construction and sales data program: http://www.census.gov/construction /nrs/about_the_surveys/.

\section{Housing Units Authorized (Building Permits)}

Monthly data on building permits for single- and multifamily housing units are released as part of the "New Residential Construction" release. The building permits data are derived from the "Building Permits Survey" (BPC), which is a representative sample of permit-issuing authorities.

\section{New Privately Owned Housing Units Started (Housing Starts)}

Monthly data on single- and multifamily housing starts, units under construction, and units completed are also released as part of the "New Residential Construction" release. A housing unit is considered to be started "when excavation begins for the footings or foundation of a building." A housing unit is considered to be completed "when all finished flooring has been installed." These data are generated by the "Survey of Construction" (SOC), which begins with a sample of individual building permits. On a 
monthly basis, census field representatives contact the individual or firm to whom the permit was issued to determine dates of starts and completions as well as physical characteristics of the units. If the unit is for sale, the eventual sales date and price are obtained, while if the unit is for rent the eventual date of occupancy (absorption) and rent are obtained.

\section{New Residential Sales (New Home Sales)}

Monthly data on new single-family homes sold, for sale, and median and average sales prices are released in the "New Residential Sales" release, the information for which is also derived from the SOC. In this data set, new single-family homes sold or for sale are defined as units "built for sale," sometimes referred to as a "spec" or speculative sale, in which the land and structure are sold in one transaction. In contrast, contractor- or ownerbuilt units are cases in which an individual or firm already owns the land and either hires a general contractor or acts as their own general contractor. Thus, new single-family homes sold are a subset of single-family housing starts and permits. A new single-family home is defined as sold "with the signing of a sales contract or the acceptance of a deposit." New singlefamily home sold and for sale can be in one of three categories: completed, under construction, or not started.

Included within the New Residential Sales data program is annual data on the characteristics of new homes sold. This information is also used to construct a quarterly Price Index for New One-Family Homes Sold Including Value of Lot, which is a constant quality price index based on hedonic methods.

\section{Housing Vacancies and Home Ownership}

Quarterly data on the housing stock of the United States and its occupancy status are derived from the Housing Vacancy Survey (HVS). Housing units are occupied, by owners or renters, or are vacant. There are several categories of vacancies including for rent, for sale, rented or sold but not yet occupied, and other. Within the other category are units held for occasional use, units temporarily occupied by persons whose usual residence is elsewhere, and other, which includes units held for settlement of an estate. Finally, there is a category of "vacant but for seasonal rather than yearround use."

\section{References}

Ambrose, Brent W. 2009. "Housing After the Fall: Reassessing the Future of the American Dream." Working Paper. Pennsylvania State University, Institute for Real Estate Studies, February. 
2010. "The Homebuilding Industry: How Did we Get Here?" Institute for Real Estate Studies 2 (Spring): 2-6.

Banerjee, Abhijit V. 1992. "A Simple Model of Herd Behavior." Quarterly Journal of Economics 107 (August): 797-817.

Case, Karl E., and Robert J. Shiller. 1989. "The Efficiency of the Market for SingleFamily Homes." American Economic Review 79 (March): 125-37.

Davis, Morris A., and Jonathan Heathcote. 2007. "The Price and Quantity of Residential Land in the United States." Journal of Monetary Economics 54 (November): $2595-620$.

Davis, Morris A., and Michael G. Palumbo. 2008. "The Price of Residential Land in Large US Cities." Journal of Urban Economics 63 (January): 352-84.

DeCoster, Gregory P., and William C. Strange. 2010. "Developers, Herding, and Overbuilding." Working Paper. Bowdoin College, Department of Economics, May.

Frey, Elaine F. 2003. "Building Industry Consolidation." Housing Economics August:7-12.

Glaeser, Edward, and Joseph Gyourko. 2008. "Arbitrage in Housing.” In Housing and the Built Environment: Access, Finance, Policy, edited by Edward Glaeser and John Quigley, 113-48. Cambridge: Lincoln Land Institute of Land Policy.

Glaeser, Edward L., Joseph Gyourko, and Albert Saiz. 2008. "Housing Supply and Housing Bubbles.” Journal of Urban Economics 64 (September): 198-217.

Haughwout, Andrew, James Orr, and David Bedoll. 2008. "The Price of Land in the New York Metropolitan Area." Current Issues in Economics and Finance, Second District Highlights 14 (3): April/May.

Mankiw, N. Gregory, and David N. Weil. 1989. "The Baby Boom, the Baby Bust, and the Housing Market." Regional Science and Urban Economics 19 (May): 235-58.

Rosenthal, Stuart S. 1999. "Residential Buildings and the Cost of Construction: New Evidence on the Efficiency of the Housing Market." The Review of Economics and Statistics 81 (March): 288-302.

Saiz, Albert. 2010. "The Geographic Determinants of Housing Supply.” Quarterly Journal of Economics 125 (August): 1253-96.

Topel, Robert, and Sherwin Rosen. 1988. "Housing Investment in the United States." Journal of Political Economy 96 (4): 718-40.

Welch, Ivo. 1992. "Sequential Sales, Learning, and Cascades." Journal of Finance 47 (June): 695-732. 